\title{
Synthesis and capsule formation of upper rim substituted tetra-acrylamido calix[4]arenes
}

\author{
Nikolai Kuhnert* and Adam Le-Gresley \\ Supramolecular and Biomolecular Chemistry Laboratory, Chemistry, School of Biomedical and \\ Molecular Sciences, C4, The University of Surrey, Guildford, UK GU2 7 XH. \\ E-mail: n.kuhnert@surrey.ac.uk; Tel:00441483876837
}

Received 15th February 2005, Accepted 14th April 2005

First published as an Advance Article on the web 4th May 2005

Upper rim substituted tetraiodo calix[4]arenes are coupled to a variety of acrylamides using the palladium catalysed Heck reaction. Tetra-acrylamido upper rim substituted calix[4]arenes are obtained in good yields with exceptionally high stereoselectivity, to produce the all-trans isomers. Tetra-acrylamido calix[4]arenes derived from secondary acrylamides are shown to dimerise via eight hydrogen bonds to form dimeric capsules, which are able to include small organic molecules.

\section{Introduction}

The main factor contributing to the stability of secondary protein structure is hydrogen bonding. In $\alpha$-helical structures and $\beta$-sheet structures trans-amide moieties form regular hydrogen bond arrays between amide $\mathrm{C}=\mathrm{O}$ and adjacent amide $\mathrm{N}-\mathrm{H}$ bonds. ${ }^{1}$ In order to achieve a sufficient degree of stability, several hydrogen bonds within a single strand ( $\alpha$-helical) or between two and more strands ( $\beta$-sheet) are necessary to maintain structural integrity. ${ }^{2}$ A transverse section through both an $\alpha$ helix (parallel to the axis isolating a quarter of amide bonds) or a $\beta$-sheet (orthogonal to the strands) reveals a topologically similar chain of hydrogen bonded amides. This chain motif is, to our knowledge, not found without the structural context of a helix or sheet in any structurally characterised peptide or protein. Thus, we wondered whether such a motif of single hydrogen bonds forming a chain of isolated interstrand amide hydrogen bonds would be stable in a synthetic system. Amide substituted calix[n]arenes could display such an unusual hydrogen bonding motif by dimerisation, although in a cyclic form, by using the structural complementarity of their $\mathrm{C}=\mathrm{O}$ and $\mathrm{N}-\mathrm{H}$ moieties. Similar hydrogen bonding motifs have been described by the groups of Rebek ${ }^{3-5}$ and Böhmer ${ }^{6}$ using a self complementary non-covalent assembly via 16 hydrogen bonds of tetra-ureido calix[4]arenes. A related dimerisation between calix[6] substituted dipeptides has recently been described by de Mendoza et al..$^{7}$ In this assembly 18 hydrogen bonds are formed between three sets of dipeptides linked to the calix[6]arene scaffold. It should be noted that both $N$-linked and $C$-linked peptide calix[4]arenes introduced by the Ungaro group ${ }^{8,9}$ did not show dimerisation by self complementary assembly, possibly due to unfavourable stereoelectronic effects or lack of secondary interactions stabilising the assembly. Related resorcinarene molecular capsules have been reported by Atwood and coworkers. ${ }^{10}$ Dimeric capsules formed by electrostatic interactions have been reported by the groups of Reinhardt and Schrader. ${ }^{11,12}$ In this contribution we like to describe in detail the synthesis and supramolecular chemistry of tetra-acrylamido calix[4]arenes. Part of this work has been reported as a short communication. ${ }^{13}$

\section{Results and discussion}

\section{Synthesis of tetra-acrylamido calix[4]arenes}

Within our research programme aimed at the synthesis of macrocyclic libraries ${ }^{14,15}$ we have recently reported on the palladium catalysed Heck reaction of tetra-iodo calix[4]arenes to produce tri- and tetra-olefinic calix[4]arenes. ${ }^{14}$ In order to expand the scope of the $\mathrm{C}-\mathrm{C}$ bond formation process, we became interested in coupling acrylamides to the broader rim of the calix[4]arene. Using our standard reaction conditions we were able to obtain a small selection of tertiary tetra-acrylamido calix[4]arenes $\mathbf{3 a - d}$ (Fig. 1) in good yields using $\mathrm{Pd}(\mathrm{OAc})_{2}$ and dppp as the catalytic system, with $\mathrm{NEt}_{3}$ as the base, in DMF. Yields and selected spectroscopic data are given in Table 1. All reactions proceed completely stereoselectively to produce the all-trans tetra-olefinic calix[4]arenes as a single stereoisomer, as indicated by the large ${ }^{3} J_{\mathrm{HC}=\mathrm{CH}}$ olefinic coupling constant between 15.5 and $16 \mathrm{~Hz}$ (see Table 1). All products are additionally found exclusively in the cone conformation. It has to be stressed that this highly chemo- and stereoselective outcome of the reaction is remarkable indeed, keeping in mind that a total of 120 reaction products are possible in this reaction including stereoisomers. ${ }^{16}$ Furthermore, it is worth noting that only very few examples of Heck coupling reactions with acrylamides have been reported. ${ }^{17}$

Secondary acrylamides $\mathbf{4 a - d}$ could be coupled successfully under similar conditions used for the tertiary acrylamides (Fig. 2). Similar to the tertiary acrylamides $\mathbf{3 a}-\mathbf{d}$ and acrylate series, ${ }^{14}$ the all-trans isomers of $\mathbf{5 a - d}$ could be obtained exclusively. The structures can be directly deduced from their NMR spectra. As discussed earlier, ${ }^{14,18}$ the difference in chemical shift $\Delta \delta$ for the two calx[4]arene methylene protons are a good indication of a close to parallel arrangement of the four olefinic substituents. Calix[4]arenes found in this particular type of conformation have been referred to as deep cavity calix[4]arenes. ${ }^{14}$ All compounds were found in the cone conformation, exhibiting NMR spectra in polar solvents with one set of signals for the four repeating units as expected for a $\mathrm{C}_{4 \mathrm{~V}}$-symmetric molecule. In all tetra-olefinic substituted derivatives the stereochemical relationship across the
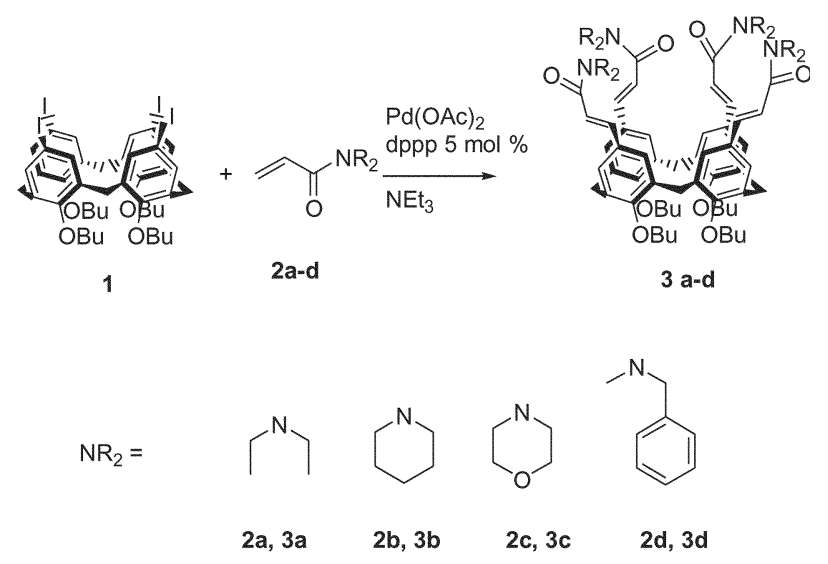

Fig. 1 Heck coupling of tertiary acrylamides. 
Table 1 Yields and selected spectroscopic data tetra-acrylamido calix[4]arenes 3a-d, 5a-d, 8 and $\mathbf{9}$

\begin{tabular}{|c|c|c|c|c|c|}
\hline Compound & $\mathrm{NR}_{2}$ & Yield $(\%)$ & Coupling constant ${ }^{3} J_{\mathrm{HC}=\mathrm{CH}} / \mathrm{Hz}$ & Coupling constant ${ }^{2} \mathbf{J}_{\mathrm{HCH}} / \mathrm{Hz}$ & Molecular ion $m / z$ \\
\hline 3a & $\mathrm{NEt}_{2}$ & 60 & 16.0 & 13.4 & 1149 \\
\hline 3b & $N$-Cyclo- $\mathrm{C}_{5} \mathrm{H}_{10}$ & 74 & 15.1 & 13.2 & 1198 \\
\hline $3 c$ & $N$-Cyclo- $i \mathrm{C}_{4} \mathrm{H}_{8} \mathrm{O}$ & 50 & 15.5 & 13.5 & 1206 \\
\hline 3d & $\mathrm{NMeBn}$ & 65 & NA & 13.4 & 1342 \\
\hline $5 a$ & $\mathrm{NH}\left(4-\mathrm{NO}_{2} \mathrm{C}_{6} \mathrm{H}_{4}\right)$ & 75 & 15.5 & 13.5 & 1409 \\
\hline $5 b$ & $\mathrm{NH}\left(4-\mathrm{CNC}_{6} \mathrm{H}_{4}\right)$ & 70 & 15.5 & 12.8 & 1329 \\
\hline $5 c$ & $\mathrm{NH}\left(4-\mathrm{CF}_{3} \mathrm{C}_{6} \mathrm{H}_{4}\right)$ & 65 & 15.1 & 13.8 & 1525 \\
\hline 5d & NHBn & 65 & 15.5 & 13.9 & 1286 \\
\hline 8 & $\mathrm{NH}\left(4-\mathrm{NH}_{2} \mathrm{C}_{6} \mathrm{H}_{4}\right)$ & 33 & 15.5 & 11.8 & 1289 \\
\hline 9 & $\mathrm{NH}\left(4-\mathrm{NHAcC} \mathrm{H}_{4}\right)$ & 49 & 15.9 & 12.1 & $1481[\mathrm{M}+\mathrm{Na}]$ \\
\hline
\end{tabular}
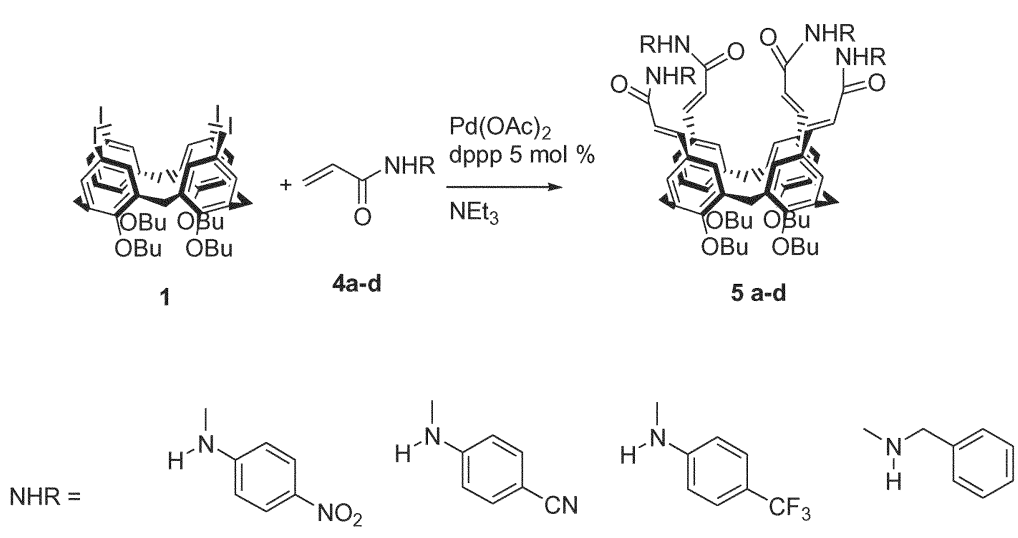

$4 a, 5 a$

$4 b, 5 b$

$4 c, 5 c$

$4 d, 5 d$

Fig. 2 Heck coupling of secondary acrylamides.

double bond is trans, as indicated by their large ${ }^{3} J_{\mathrm{HC}=\mathrm{CH}}$ olefinic coupling constants between 14.9 to $15.5 \mathrm{~Hz}$. Yields and selected spectroscopic data are given in Table 1.

\section{Hydrogen bonding and dimerisation}

In solvents competing for hydrogen bonding, such as DMSO and acetone, the ${ }^{1} \mathrm{H}-\mathrm{NMR}$ spectra of compounds $\mathbf{3 a - d}$ and $\mathbf{5 a}-$ d revealed one set of signals per repeating unit in agreement with their overall $\mathrm{C}_{4 \mathrm{v}}$-symmetry. In non-polar solvents, such as $\mathrm{CDCl}_{3}, \mathrm{CD}_{2} \mathrm{Cl}_{2}, \mathrm{C}_{2} \mathrm{D}_{2} \mathrm{Cl}_{4}$ and $\mathrm{C}_{6} \mathrm{D}_{6}$, however, the spectra changed completely for compounds $\mathbf{5 a}-\mathbf{c}$. For compounds $\mathbf{5 a}, \mathbf{5 b}$ and $\mathbf{5} \mathbf{c}$ in $\mathrm{CDCl}_{3}$ two sets of signals for the aromatic calix[4]arene protons were apparent. For a detailed description we limit ourselves to compound $\mathbf{5 b}$. A new sharp set of signals displaying two aromatic signals at unusual high-fields at $5.88 \mathrm{ppm}$ and $6.76 \mathrm{ppm}$ and a $\mathrm{N}-\mathrm{H}$ proton signal at $11.20 \mathrm{ppm}$ was observed. This observation is indicative of a dimerisation process involving hydrogen bonding that reduces the rotational barrier around the $\mathrm{C}_{\mathrm{Ar}}-\mathrm{C}=\mathrm{C}$ bond, hence giving rise to a pair of non-equivalent aromatic protons (see Fig. 3). Both ${ }^{1} \mathrm{H}^{1} \mathrm{H}-\mathrm{COSY}$ and ${ }^{1} \mathrm{H}^{13} \mathrm{C}$ HMQC spectra confirmed this assignment. The ${ }^{1} \mathrm{H}^{15} \mathrm{~N}-\mathrm{HMQC}$ revealed one cross peak corresponding to the H-bonded $\mathrm{N}-$ $\mathrm{H}$ of $\mathbf{5 b} \cdot \mathbf{5 b}$ at $136 \mathrm{ppm}$. Compounds $\mathbf{3 a - d}$, as tertiary amides lacking the ability to form hydrogen bonds, and compound $\mathbf{5 d}$, lacking the ability to form a dimer presumably due to a lack of favourable aromatic $\pi-\pi$ interactions that further stabilise a dimeric structure, did not show the behaviour described above. Experimental evidence for aromatic $\pi-\pi$ interactions can be found in the chemical shifts in the ${ }^{1} \mathrm{H}-\mathrm{NMR}$ spectra of the dimeric species in $\mathrm{CDCl}_{3}$. The ESI-mass spectra for the dimeric compounds $\mathbf{5 a} \cdot \mathbf{5 a}, \mathbf{5 b} \cdot \mathbf{5 b}$ and $\mathbf{5 c} \cdot \mathbf{5 c}$ in methanol recorded in the negative ion mode show the dimeric compound with one molecule of methanol included, presumably in the centre of the capsule. As a representative example, the ESI spectra of $\mathbf{5 b} \cdot \mathbf{5 b} \cdot \mathbf{M e O H}$ with a molecular ion at $\mathrm{m} / \mathrm{z} 2689.2$ is shown in Fig. 4. In contrast, the FAB mass spectra show the molecular ion of the monomeric calix[4]arene exclusively.

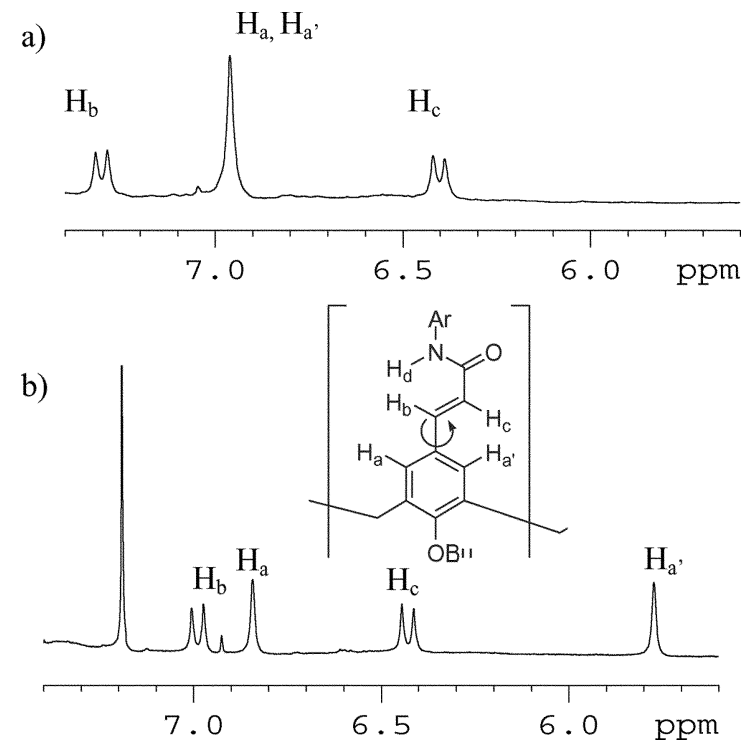

Fig. 3 Expanded $500 \mathrm{MHz}{ }^{1} \mathrm{H}-\mathrm{NMR}$ spectra of (a) $\mathbf{5 b}$ (in DMSO) with low barrier of rotation around $\mathrm{C}_{\mathrm{Ar}}-\mathrm{C}=\mathrm{C}$; (b) $\mathbf{5 b} \cdot \mathbf{5 b}$ (in $\mathrm{CDCl}_{3}$ ) restricted around $\mathrm{C}_{\mathrm{Ar}}-\mathrm{C}=\mathrm{C}$.

We propose structure $\mathbf{5 b} \cdot \mathbf{5 b}$ (Fig. 5 and Fig. 6) for the hydrogen bonded dimer, that is in full agreement with semi-quantitative NOE data and the ASIS effects based on the McConnell equation. ${ }^{20}$ The detailed hydrogen bonding is shown in Fig. 6. Dimerisation occurs via only eight hydrogen bonds, half the number reported for most previous examples, ${ }^{4-6}$ between $\mathrm{C}=\mathrm{O}$ and $\mathrm{N}-\mathrm{H}$ moieties of opposing acrylamides. The amide occupies the trans geometry in all cases. The capsule geometry resembles topologically the tetra-ureido hydrogen bonded capsules reported by Böhmer and Rebek, ${ }^{4,6}$ with a seam of hydrogen bonds in the "equatorial" position. The two halves of the capsules are enantiomeric and the hydrogen bond array forms a cyclic stereogenic element. The electron deficient $p$ - $\mathrm{CN}$-aryl 


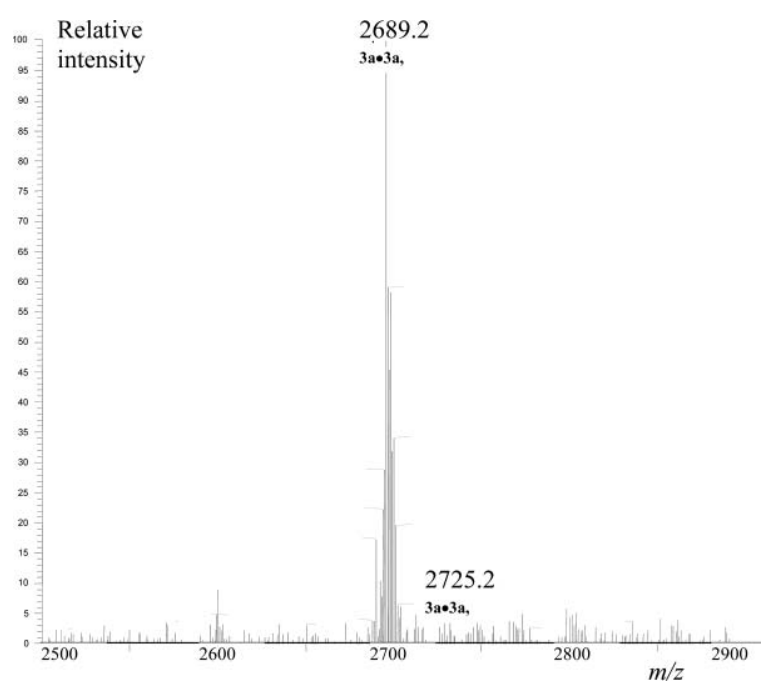

Fig. 4 Expanded region of ESI-mass spectrum of $\mathbf{5 b} \cdot \mathbf{5 b} \cdot \mathbf{M e O H}$ (recorded in the negative ion mode)

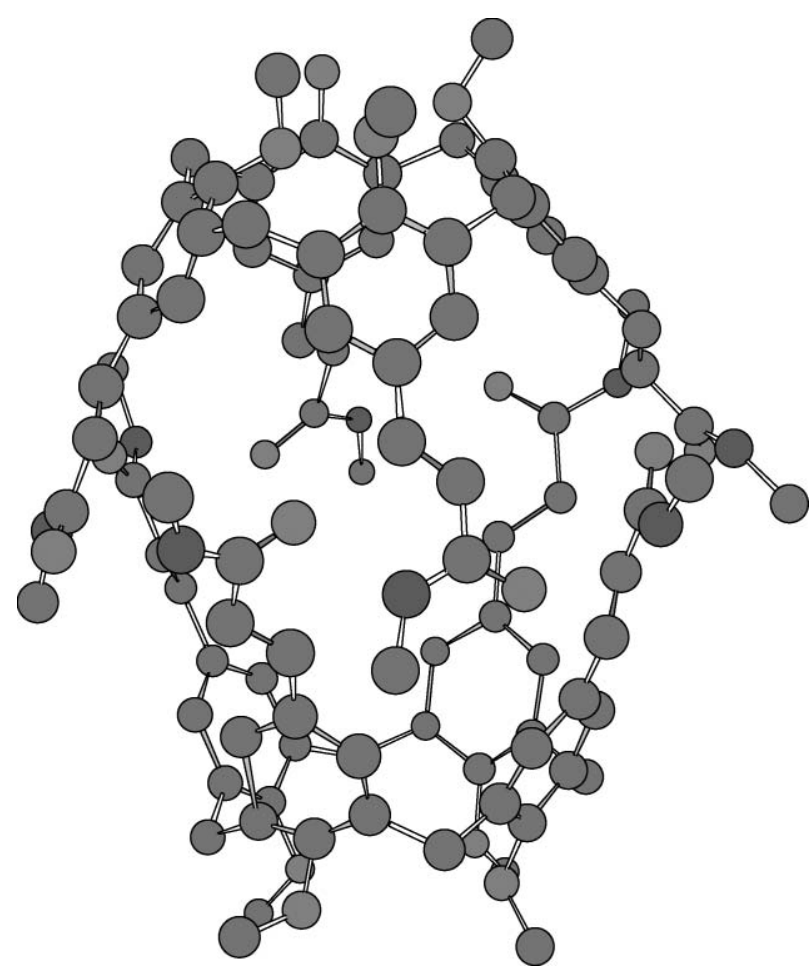

Fig. 5 Proposed 3D structure of dimeric capsule $\mathbf{5} \mathbf{b} \cdot \mathbf{5} \mathbf{b}$ obtained by ASIS and NOE data (Hs, $n$-Bu and aromatic residues have been omitted for clarity). ${ }^{13}$ group interacts "face to face" with the electron rich aromatic moiety of the calix[4]arene, adding a further element of stability. This interaction follows from the ASIS shift induced on to the high field aromatic calix[4]arene proton $\mathrm{H}_{\mathrm{a}^{\prime}}$ at $5.89 \mathrm{ppm}$ (see Fig. 3). The hydrogen bonding array resembles topologically a transverse slice through a $\beta$-sheet structure, as discussed above, in which a single amide in one strand binds to a single amide in a second strand in a cyclic manner.

Further evidence for the dimeric capsule structure comes from two classic experiments devised by the Böhmer group. ${ }^{19,20}$ The addition of benzene to a $\mathrm{CDCl}_{3}$ solution of $\mathbf{5 b} \cdot \mathbf{5} \mathbf{b}$ results in the appearance of a high field signal at $4.52 \mathrm{ppm}$ in the ${ }^{1} \mathrm{H}$ NMR spectrum. A signal at a comparable chemical shift was assigned to a benzene molecule encapsulated in a tetra-ureido calix[4]arene dimer by Böhmer and Cohen. ${ }^{21} \mathrm{~A}$ similar inclusion complex could be observed with the pesticides tetramethylthiuram-disulfide $\mathbf{6}$ or triazine $\mathbf{7}$ as a guest (Fig. 7). The two methyl resonances of $\mathbf{6}$ are shifted towards higher field on encapsulation, from e.g. $3.52 \mathrm{ppm}$ to $3.21 \mathrm{ppm}$. The uptake of this guest is relatively slow $\left(t_{1 / 2} \sim 36 \mathrm{~h}\right.$ in $\mathrm{CDCl}_{3}$ at $4.1 \mathrm{mM}$ of $\mathbf{6}$ and $\mathbf{5 b} \cdot \mathbf{5 b})$ as estimated by ${ }^{1} \mathrm{H}-\mathrm{NMR}$ spectroscopy. Further evidence for the encapsulation of $\mathbf{6}$ results from diffusion NMR experiments. On encapsulation the diffusion coefficient of $\mathbf{6}$ changes from $2.08 \times 10^{-10} \mathrm{~m}^{2} \mathrm{~s}^{-1}$ to $7.89 \times 10^{-11} \mathrm{~m}^{2} \mathrm{~s}^{-1}$. The latter diffusion coefficient corresponds to the value found for $\mathbf{5 b} \cdot \mathbf{5 b}$. Similar changes in diffusion coefficient, along with chemical shift changes in the ${ }^{1} \mathrm{H}-\mathrm{NMR}$ spectrum, are observed for the inclusion complex with triazine $\mathbf{5 b} \cdot \mathbf{5 b} \cdot \mathbf{7}$ accompanied by a change of diffusion coefficient from $2.2 \times 10^{-10} \mathrm{~m}^{2} \mathrm{~s}^{-1}$ to $7.90 \times$ $10^{-11} \mathrm{~m}^{2} \mathrm{~s}^{-1}$ on encapsulation. Change in a diffusion coefficient is in line with encapsulation, as discussed by Cohen et al. ${ }^{21,22}$ Encapsulation appears to be irreversible. If inclusion complex $\mathbf{5 b} \cdot \mathbf{5 b} \cdot \mathbf{7}$ is treated with an excess of $\mathbf{6}$ no exchange of the included guest is apparent after $400 \mathrm{~h}$ by ${ }^{1} \mathrm{H}-\mathrm{NMR}$ spectroscopy and the same was observed for the reverse experiment, in which inclusion complex $\mathbf{5 b} \cdot \mathbf{5 b} \cdot \mathbf{6}$ was treated with an excess of 7 .
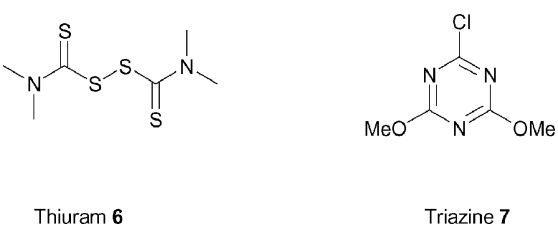

Fig. 7 Encapsulated guest molecules.

\section{Heterodimerisation}

Finally, and most importantly, an equimolar mixture of $\mathbf{5 a}$ and $\mathbf{5 b}$ in $\mathrm{CDCl}_{3}$ gives rise to the formation of heterodimeric capsules. In the ${ }^{1} \mathrm{H}-\mathrm{NMR}$ spectrum four $\mathrm{N}-\mathrm{H}$ signals corresponding to the four different $\mathrm{N}-\mathrm{H}$ protons of the three species present in solution $\mathbf{5 a} \cdot \mathbf{5 a}, \mathbf{5 a} \cdot \mathbf{5 b}$ and $\mathbf{5 b} \cdot \mathbf{5 b}$ are observed in a statistical ratio

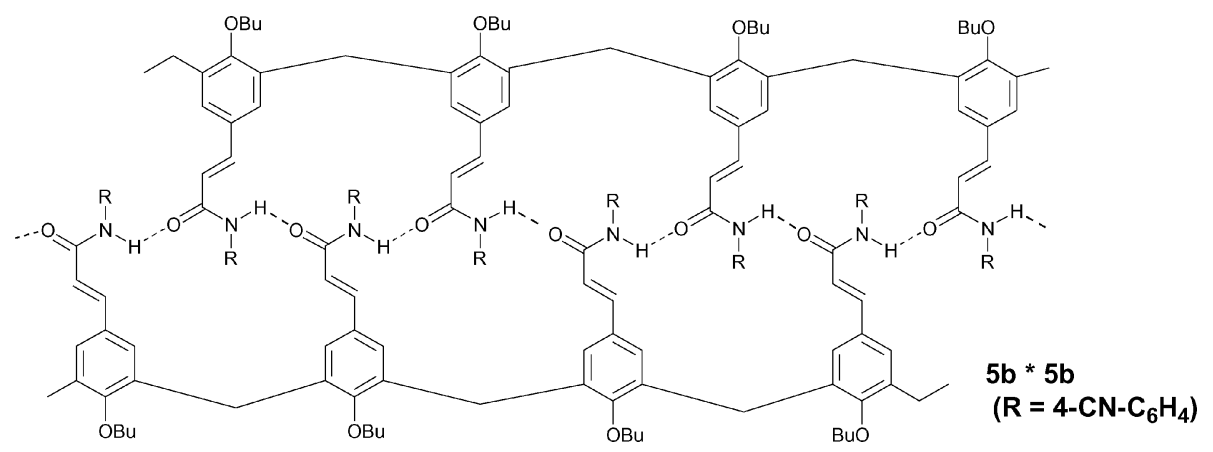

Fig. 6 2D representation of schematic hydrogen-bonding array in dimeric capsule $\mathbf{5 b} \cdot \mathbf{5 b}$ (note that $\mathrm{C}-\mathrm{C}$ bonds completing the macrocyclic structure have been omitted for clarity). 
of $1: 2: 1$ at $8.2 \mathrm{mM}$ concentration of a mixture of $\mathbf{5 a}$ and 5b in $\mathrm{CDCl}_{3}$ (see Fig. 8). The three required molecular ions for the three heterodimeric species can also be observed in the ESI spectra of the mixture of $\mathbf{5 b} \mathbf{5} \mathbf{5 b}$ in methanol in the negative ion mode. Similar heterodimers are observable for mixtures of $\mathbf{5 b}$ and $\mathbf{5 c}$ as well as $\mathbf{5 a}$ and $\mathbf{5 c}$.

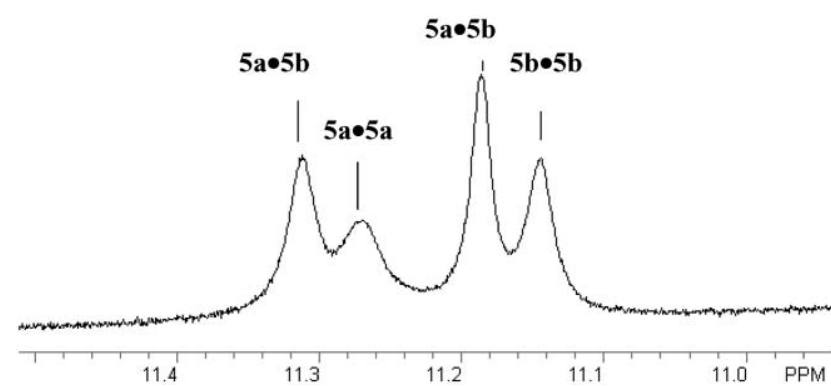

Fig. 8 Expanded $500 \mathrm{MHz}{ }^{1} \mathrm{H}-\mathrm{NMR}$ spectrum in $\mathrm{CDCl}_{3}$ of the amide region showing four $\mathrm{N}-\mathrm{H}$ signals corresponding to $\mathbf{5 a} \cdot \mathbf{5 a}, \mathbf{5 a} \cdot \mathbf{5 b}$ and $\mathbf{5 b} \cdot \mathbf{5 b}$.

\section{Aggregation in $\mathrm{C}_{2} \mathrm{D}_{2} \mathrm{Cl}_{4}$}

Suprisingly, in addition to the dimeric capsule $\mathbf{5 b} \cdot \mathbf{5 b}$ (in this section referred to as a $\mathbf{5 b} \cdot \mathbf{5 b}(\mathbf{A}))$ we observed a second calix[4]arene species (referred to here as $\mathbf{5 b} \cdot \mathbf{5 b}(\mathbf{B})$ ) in $\mathrm{CD}_{2} \mathrm{Cl}_{4}$, showing almost identical spectral data as compared to $\mathbf{5 b} \cdot \mathbf{5 b}$ in $\mathrm{CDCl}_{3}$. The second calix[4]arene aggregate displays a full set of broad ${ }^{1} \mathrm{H}$ - and ${ }^{13} \mathrm{C}$-signals required for a calix[4] arene (see Fig. 9). Regarding the second calix[4]arene assembly $\mathbf{5 b} \cdot \mathbf{5 b}(\mathbf{B})$, we have no unambigious definite structural information but a vast amount of further data that allows some careful suggestions with regard to its chemical nature.

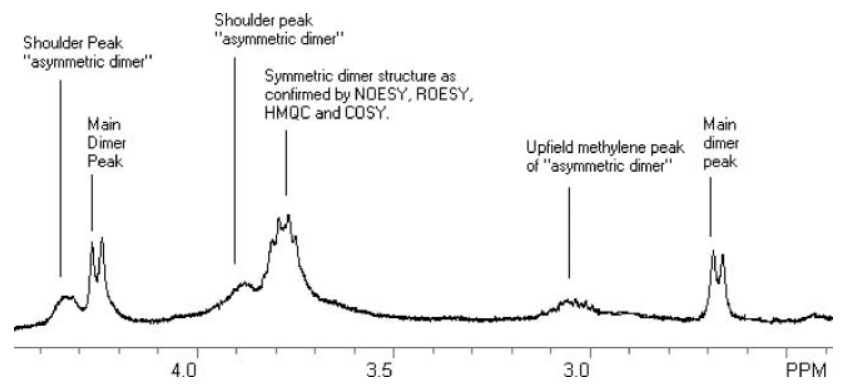

Fig. $9{ }^{1} \mathrm{H}-\mathrm{NMR}$ spectrum of $\mathbf{5 b} \cdot \mathbf{5 b}(\mathbf{A})$ and $\mathbf{5 b} \cdot \mathbf{5 b}(\mathbf{B})$ in $\mathrm{C}_{2} \mathrm{D}_{2} \mathrm{Cl}_{4}$ $(500 \mathrm{MHz})$.

It has been argued by Rebek and Böhmer ${ }^{3-5,19}$ that dimerisation via hydrogen bonds of tetraureido calix[4]arenes is templated by small guests and that in the absence of these guests loose hydrogen bonded aggregates are formed, resulting in ill defined, broad NMR spectra. Careful addition of chloroform to the mixture did, however, reveal that the ratio of $\mathbf{5 b} \cdot \mathbf{5 b}(\mathbf{A})$ to $\mathbf{5 b} \cdot \mathbf{5 b}$ (B) remained largely unaffected at low chloroform concentrations. Only by using a chloroform excess of $>1000$, the concentration of $\mathbf{5 b} \cdot \mathbf{5 b}(\mathbf{B})$ was significantly reduced and the signal intensity of $\mathbf{5 b} \cdot \mathbf{5 b}(\mathbf{A})$ increased. We also considered that an impurity in our $\mathrm{C}_{2} \mathrm{D}_{2} \mathrm{Cl}_{4}$ might affect the dimerisation process, however, no impurities could be detected by GC-MS and NMR spectroscopy. From the ${ }^{1} \mathrm{H}-{ }^{1} \mathrm{H}-\mathrm{NOESY}$ spectra we can conclude that due to the absence of any exchange peaks between of $\mathbf{5 b} \cdot \mathbf{5 b}(\mathbf{A})$ and $\mathbf{5 b} \cdot \mathbf{5 b}(\mathbf{B})$ the exchange between these species is very slow on the NMR time scale. The signals in the ${ }^{1} \mathrm{H}$ NMR spectrum corresponding to $\mathbf{5 b} \cdot \mathbf{5 b}(\mathbf{B})$ are broad. Possible explanations for this include a high molecular weight, a dynamic exchange process or both. At lower temperature $\left(-60{ }^{\circ} \mathrm{C}\right)$ the lines of $\mathbf{5 b} \mathbf{b} \mathbf{5 b}(\mathbf{B})$ broaden considerably, suggesting approaching coalescence and a dynamic exchange process.
A further calix[4]arene assembly spectroscopically similar to $\mathbf{5 b} \cdot \mathbf{5 b}$ (B), characterised by broad signals at roughly identical chemical shifts can be observed on addition of $\frac{1}{8}$ mol eq. of acrylamide or $p-\mathrm{CN}-\mathrm{Ar}$-acrylamide to the dimeric structure $\mathbf{5 b} \cdot \mathbf{5 b}$ in $\mathrm{CDCl}_{3}$ producing $\mathbf{5 b} \cdot \mathbf{5 b} \cdot \mathbf{H}_{\mathbf{2}} \mathbf{N C}=\mathbf{O H C}=\mathbf{C H}_{\mathbf{2}}$. Similarily, addition of acrylamide to the two aggregates in $\mathrm{C}_{2} \mathrm{D}_{2} \mathrm{Cl}_{4}$ resulted in the disappearance of the signals corresponding to $\mathbf{5 b} \cdot \mathbf{5 b}$ (A) and a new set of signals corresponding to $\mathbf{5 b} \cdot \mathbf{5 b} \cdot \mathrm{H}_{2} \mathbf{N C}=\mathbf{O H C}=\mathrm{CH}_{2}$ appeared

A diffusion NMR experiment of $\mathbf{5 b} \cdot \mathbf{5 b}(\mathbf{B})$ in $\mathrm{CDCl}_{3}$ and $\mathrm{C}_{2} \mathrm{D}_{2} \mathrm{Cl}_{4}$ using two well separated high field $\mathrm{CH}_{2}$ multiplets of the two aggregates revealed the following diffusion constants: $5.3 \times 10^{-9} \mathrm{~m}^{2} \mathrm{~s}^{-1}$ for $\mathbf{5 b} \cdot \mathbf{5 b}, 5.3 \times 10^{-9} \mathrm{~m}^{2} \mathrm{~s}^{-1}$ for $\mathbf{5 b} \cdot \mathbf{5 b} \cdot \mathbf{4 b}$ and $5.4 \times 10^{-9} \mathrm{~m}^{2} \mathrm{~s}^{-1}$ for $\mathbf{5 b} \cdot \mathbf{5 b}(\mathbf{B})$. These data clearly indicate that the hydrodynamic radius of all three components is virtually identical. All three aggregates must therefore be dimeric calix[4]arene species, although $\mathbf{5 b} \cdot \mathbf{5 b}(\mathbf{B})$ and $\mathbf{5 b} \cdot \mathbf{5 b} \cdot \mathbf{4 b}$ with a reduced symmetry induced by host-guest chemistry.

The nature of the guest molecule interacting with the hydrogen bond motif is subject to some speculation.

${ }^{1} \mathrm{H}-\mathrm{NMR}$ spectra of $\mathbf{5 b} \mathbf{b} \mathbf{5} \mathbf{b}(\mathbf{A})$ in $\mathrm{C}_{2} \mathrm{D}_{2} \mathrm{Cl}_{4}$ change considerably with increasing temperature. The non-equivalent two singlets of the aromatic protons in the $\mathbf{5 b} \cdot \mathbf{5 b}(\mathbf{A})$ dimeric capsule seem to coalesce into one singlet. Coalescence temperature can be observed around $320 \mathrm{~K}$. This process can be explained by the rupture of the dimeric structure at higher temperatures giving two monomeric 5b. Alternatively, this NMR behaviour can be rationalised by assuming rapid rotation around $\mathrm{Ar}-\mathrm{CH}=$ in an intact dimeric structure. Similarly, increasing the temperature of $\mathbf{5 b} \cdot \mathbf{5 b}(\mathbf{A})$ in $\mathrm{C}_{2} \mathrm{D}_{2} \mathrm{Cl}_{4}$ results in the steady collapse of the methylene doublet at $\delta 2.70 \mathrm{ppm}$ and the growth of a doublet at $\delta 3.2 \mathrm{ppm}$, suggesting the adoption of a more pinched cone conformation.

\section{Estimation of dimerisation constant}

In any supramolecular system the estimation of the dimerisation constant is important. In the case presented this is not a straightforward task. In the NMR spectra the chemical shift for the monomer in the solvents of interest is unknown and, therefore, a NMR shift titration not feasible. Due to the success of our diffusion NMR experiments we decided to use diffusion NMR to estimate the dimerisation constant. It has been reported that in supramolecular systems the diffusion constant is dependent on the relative concentration of monomer and dimer. ${ }^{23}$ The diffusion constant $D$ was determined for compound $\mathbf{5 b} \cdot \mathbf{5 b}$ for five different concentrations in $\mathrm{CDCl}_{3}$, using a ${ }^{1} \mathrm{H}$-cryoprobe at $500 \mathrm{MHz}$ with $z$-field gradients. Indeed, a difference in diffusion constant larger than the estimated error of the experiment could be observed. The data obtained are shown in Fig. 10. From the data a dimerisation constant, using standard curve fitting of the appropriate binding model, ${ }^{23}$ of $4600 \pm 900 \mathrm{M}^{-1}$ was estimated. Due to the relatively large error of the diffusion constant measurements $( \pm 10-15 \%)$, in particular at low concentrations, an error of $20 \%$ was estimated for the dimerisation constant.

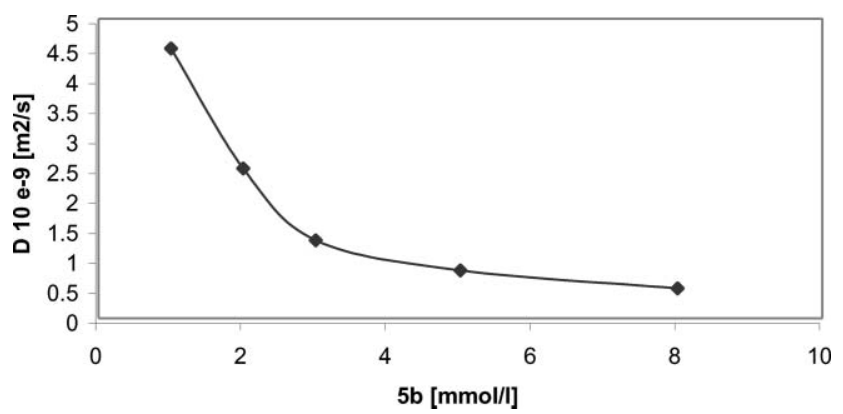

Fig. 10 Plot of diffusion constant $D$ versus concentration of $\mathbf{5 b}$ in $\mathrm{CDCl}_{3}$. 


\section{Extended Acrylamides}

Following the observation that tetra-acrylamido calix[4]arenes derived from secondary acrylamides form dimeric capsules in solution, we decided to synthesise compounds that display two such hydrogen bonding motifs. In this case it might be possible to obtain dimeric capsules of different sizes from the same monomer and eventually control the size by judicious choice of conditions. Hence, we reduced nitro compound $\mathbf{5 a}$ using stannous chloride to give tetra-amine $\mathbf{8}$ in moderate yield. Acetylation of $\mathbf{8}$ gave octa-amide $\mathbf{9}$, displaying two distinct sets of hydrogen bonding motifs (Fig. 11). However, the purity of 9 was unsatisfactory and we obtained $\mathbf{9}$ in an alternative synthetic approach using a direct Heck coupling strategy as before, this time to obtain 9 in satisfactory purity. The spectroscopic data of $\mathbf{8}$ and 9 are as expected and mirror those of $\mathbf{3 a - d}$ and $\mathbf{5 a - d}$. Unfortunately, 9 is only soluble in DMSO and not in unpolar solvents such as chloroform, which thus prevents any detailed analysis of the dimerisation process in less polar solvents as discussed above.

\section{Conclusion}

We have synthesised tetra-acrylamido upper rim calix[4]arene derivatives and applied the Heck reaction to the synthesis of functionalised calix[4]arenes. All reactions proceed in good yield and give stereoselectively the all-trans tetra-olefinic calix[4]arenes.

Calix[4]arenes derived from secondary acrylamides have been shown to dimerise in non polar solvents to give molecular capsules using eight $\mathrm{N}-\mathrm{H}-\mathrm{O}=\mathrm{C}$ hydrogen bonds and a series of aromatic aromatic interactions.

\section{Experimental}

${ }^{1} \mathrm{H}$ - and ${ }^{13} \mathrm{C}-\mathrm{NMR}$ spectra were recorded on a JEOL GSX $270 \mathrm{MHz}$ and a Bruker Avance $500 \mathrm{MHz}$ spectrometer, $\delta$ values are quoted relative to teramethylsilane $\left(\delta_{\mathrm{H}} 0.00 \mathrm{ppm}\right)$ or chloroform $\left(\delta_{\mathrm{H}} 7.23 \mathrm{ppm}\right)$ for ${ }^{1} \mathrm{H}-\mathrm{NMR}$ and relative to chloroform $\left(\delta_{\mathrm{C}} 77.0 \mathrm{ppm}\right)$ for ${ }^{13} \mathrm{C}$-NMR. Coupling constants $J$ are in Hz. Microanalysis were carried out using a Leeman CE 440 automatic elemental analyser. Due to the hygroscopic nature of the calix[4]arenes, water inclusion molecules are incorporated into the microanalytical data. Infrared spectra were determined on a Perkin Elmer 200 Spectrometer. The FAB and CI mass spectra were recorded using a ThermoQuest Finnigan MAT $95 \mathrm{XL}$ spectrometer. ESI-MS spectra were recorded on a ThermoFinnigan DECA CQXP Plus.

Thin layer chromatography (TLC) was carried out on commercially available precoated plates (Merck Kieselgel 60 F254 silica) using $1: 3$ ethylacetate-hexane as a solvent sysytem. Flash column chromatography at a pressure of 1 bar was carried out on Merck Kieselgel 60 (230-400 mesh) silica. All chemicals/reagents were purchased from the Aldrich Chemical
Company. Solvents were dried using the usual procedures and reagents used without further purification unless stated otherwise. Calix[4]arenes 1 were prepared according to the literature procedure. ${ }^{14}$

\section{General procedure for the preparation of acrylamides}

$\mathrm{Et}_{3} \mathrm{~N}(8.23 \mathrm{ml})$ and the amine $(27 \mathrm{mmol})$ were stirred in DCM $75 \mathrm{ml}$ for $10 \mathrm{~min}$ at $\mathrm{rt}$. Acryloyl chloride $(2.66 \mathrm{ml})$ was very slowly added with the temperature being maintained at $\mathrm{rt}$. The reaction was monitored via TLC or NMR. Upon completion, the reaction was quenched with iced water $(200 \mathrm{ml})$ and the organic component extracted with DCM $(3 \times 50 \mathrm{ml})$. The combined organic extracts were washed with $\mathrm{HCl}(3 \times 40 \mathrm{ml}$, $3 \mathrm{M})$, water $(2 \times 50 \mathrm{ml}) \mathrm{NaOH}(3 \times 30 \mathrm{ml}, 2 \mathrm{M})$ and again with water $(2 \times 50 \mathrm{ml})$. The organic extract was dried $\left(\mathrm{Na}_{2} \mathrm{SO}_{4}\right)$, filtered and evaporated under a reduced pressure. Solid acrylamides could be recrystalised from hot methanol and all acrylamides were stored below $0{ }^{\circ} \mathrm{C}$ or used immediately.

Diethylacrylamide $2 \mathbf{a}^{24}$. Pale yellow oil $(78 \%) ; \delta_{\mathrm{H}}(270 \mathrm{MHz}$; $\left.\mathrm{CDCl}_{3}\right) 6.25\left(1 \mathrm{H}, \mathrm{dd}, J 17.4,10.2 \mathrm{H}_{\mathrm{c}}\right), 7.40\left(1 \mathrm{H}, \mathrm{d}, J 17.4, \mathrm{H}_{\mathrm{e}}\right)$, $5.62\left(1 \mathrm{H}, \mathrm{d}, J 10.2, \mathrm{H}_{\mathrm{d}}\right), 3.32\left(4 \mathrm{H}, \mathrm{q}, J 5.8, \mathrm{H}_{\mathrm{h}}\right), 1.10(6 \mathrm{H}, \mathrm{t}, J$ $\left.5.8, \mathrm{H}_{\mathrm{a}}\right)$.

Benzylacrylamide $\quad \mathbf{4 d}^{24}$. Pale orange shards (78\%); $\delta_{\mathrm{H}}\left(500 \mathrm{MHz} ; \mathrm{CDCl}_{3}\right) 7.32-7.24\left(5 \mathrm{H}, \mathrm{m}, \mathrm{H}_{\mathrm{a}}, \mathrm{H}_{\mathrm{b}}, \mathrm{H}_{\mathrm{c}}\right)$, $6.52\left(1 \mathrm{H}, \mathrm{s}\right.$ (broad), $\left.\mathrm{H}_{\mathrm{g}}\right), 6.28\left(1 \mathrm{H}, \mathrm{dd}, J 17.8,1.4 \mathrm{H}_{\mathrm{e}}\right), 7.40(1 \mathrm{H}$, $\left.\mathrm{dd}, J 17.8,10.3, \mathrm{H}_{\mathrm{d}}\right), 5.62\left(1 \mathrm{H}, \mathrm{dd}, J 10.3,1.4, \mathrm{H}_{\mathrm{f}}\right), 4.46(2 \mathrm{H}, \mathrm{d}$, $J$ 5.6, $\left.\mathrm{H}_{\mathrm{h}}\right)$.

5,11,17,23-Tetrakis $[(E)$ - $N$-(diethyl)-acrylamido]-25,26,27,28tetra-n-butoxycalix[4]arene 3a. Triethylamine $(0.335 \mathrm{ml}, 0.157 \mathrm{~g}$, $1.56 \mathrm{mmol})$ and diethylacrylamide $2 \mathrm{a}(0.264 \mathrm{~g}, 2.08 \mathrm{mmol})$ was added to a stirred solution of 5,11,17,23-tetraiodocalixarene$25,26,27,28$-tetra- $n$-butylether $(0.3 \mathrm{~g}, 0.26 \mathrm{mmol}) \mathbf{1}$ in DMF $(20 \mathrm{ml})$. After $10 \mathrm{~min}$ of vigorous stirring at $25^{\circ} \mathrm{C}$, palladium acetate $(0.006 \mathrm{~g}, 0.026 \mathrm{mmol})$ and diphenylphosphinopropane $(0.011 \mathrm{~g}, 0.026 \mathrm{mmol})$ were added, the mixture heated to $100^{\circ} \mathrm{C}$ and stirred for $300 \mathrm{~h}$.

After addition of $50 \mathrm{ml}$ diethylether the mixture was washed with $\mathrm{HCl}(3 \times 20 \mathrm{ml}, 3 \mathrm{M})$. The organic extract was dried $\left(\mathrm{Na}_{2} \mathrm{SO}_{4}\right)$, filtered and evaporated under a reduced pressure. The residue was further dried in a desiccator $\left(\mathrm{SiO}_{2}\right)$ under a reduced pressure for $12 \mathrm{~h}$ and purified via column chromatography $\left(\mathrm{SiO}_{2}\right.$, EtOAc-hexane $1: 1)$ to give the calix[4]arene 3a $(0.15 \mathrm{~g}, 51 \%)$ as off-white cubes; $\mathrm{mp} 120-122^{\circ} \mathrm{C}$; $v_{\max }(\mathrm{Nujol}) / \mathrm{cm}^{-1} 1620(\mathrm{C}=\mathrm{C})$, $1645(\mathrm{C}=\mathrm{O}) ; \delta_{\mathrm{H}}\left(270 \mathrm{MHz} ; \mathrm{CDCl}_{3}\right) 7.31(4 \mathrm{H}, \mathrm{d}, J 16.0, \mathrm{Ar}-$ $\mathrm{CH}=), 6.81(8 \mathrm{H}, \mathrm{s}, \mathrm{Ar}-\mathrm{H}), 6.39(4 \mathrm{H}, \mathrm{d}, J 16.0, \mathrm{Ar}-\mathrm{CH}=\mathrm{CH}-$ $\mathrm{C}=\mathrm{O}), 4.41\left(4 \mathrm{H}, \mathrm{d}, J 13.4, \mathrm{CH}_{\mathrm{A}} \mathrm{H}_{\mathrm{B}} \mathrm{Ar}\right), 3.83\left(8 \mathrm{H}, \mathrm{t}, J 6.4, \mathrm{CH}_{2} \mathrm{O}\right)$, $3.4-3.2\left(16 \mathrm{H}, \mathrm{m}, \mathrm{NCH}_{2}\right), 3.19\left(4 \mathrm{H}, \mathrm{d}, J 13.4, \mathrm{CH}_{\mathrm{A}} H_{\mathrm{B}} \mathrm{Ar}\right), 1.90$ $\left(8 \mathrm{H}, \mathrm{m}, \mathrm{CH}_{2} \mathrm{CH}_{2} \mathrm{O}\right), 1.50-1.35\left(8 \mathrm{H}, \mathrm{m}, \mathrm{OCHCH}_{2} \mathrm{CH}_{2}\right), 1.05$ $1.20\left(24 \mathrm{H}, \mathrm{m} \mathrm{NCH} \mathrm{CH}_{3}\right), 1.00\left(12 \mathrm{H}, \mathrm{t}, J 8.3, \mathrm{CH}_{3} \mathrm{CH}_{2}\right) ; \delta_{\mathrm{c}}$ $\left(\mathrm{CDCl}_{3}\right)$ 164.7, 159.4, 142.6, 126.3, 124.5, 123.2, 119.8, 72.2, $45.6,40.3,32.3,31.2,19.4,14.1,13.2 ; \mathrm{m} / z$ (EI) $1149[\mathrm{M}+]$.

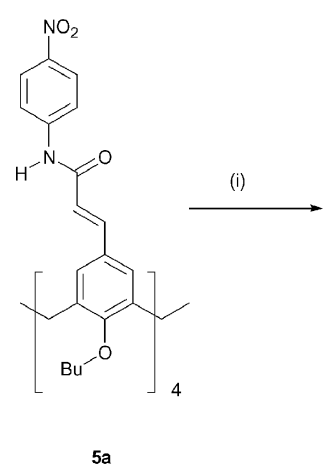

$5 a$
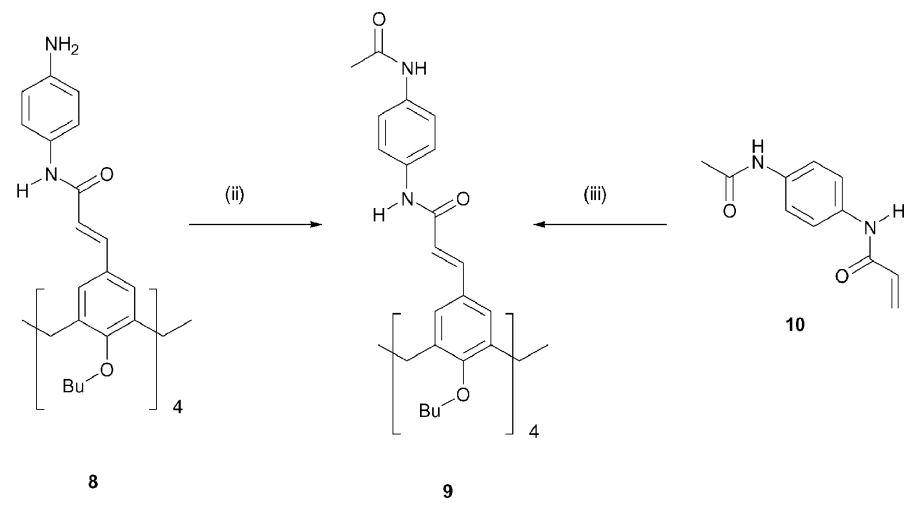

Fig. 11 Reagents and conditions: (i) $\mathrm{SnCl}_{2}-\mathrm{HCl}$; (ii) $\mathrm{Ac}_{2} \mathrm{O}, \mathrm{NEt}_{3}$; (iii) 1, $\mathrm{NEt}_{3}-15 \% \mathrm{Pd}(\mathrm{OAc}) 2, \mathrm{dppp}, \mathrm{DMF}, 100{ }^{\circ} \mathrm{C}, 275 \mathrm{~h}$. 
Found C, 68.95; H, 8.37; N, 4.56\% $\mathrm{C}_{72} \mathrm{H}_{100} \mathrm{O}_{8} \mathrm{~N}_{4} \cdot 6 \mathrm{H}_{2} \mathrm{O}$ requires $\mathrm{C}, 68.76 ; \mathrm{H}, 8.98 ; \mathrm{N}, 4.50 \%$

$5,11,17,23$-Tetrakis $[(E)-N$-(piperidyl)-acrylamido]-25,26,27, 28-tetra-n-butoxycalix[4]arene 3b. Triethylamine $(0.335 \mathrm{ml}$, $0.157 \mathrm{~g}, 1.56 \mathrm{mmol})$ and piperidylacrylamide $2 \mathrm{~b}(0.289 \mathrm{~g}$, $2.08 \mathrm{mmol}$ ) were added to a stirred solution of $5,11,17,23-$ tetraiodocalixarene-25,26,27,28 - tetra- $n$-butylether $(0.3 \mathrm{~g}$, $0.26 \mathrm{mmol}) 1$ in DMF $(20 \mathrm{ml})$. After $10 \mathrm{~min}$ of vigorous stirring at $25^{\circ} \mathrm{C}$, palladium acetate $(0.006 \mathrm{~g}, 0.026 \mathrm{mmol})$ and diphenylphosphinopropane $(0.011 \mathrm{~g}, 0.026 \mathrm{mmol})$ were added, the mixture heated to $100{ }^{\circ} \mathrm{C}$ and stirred for $325 \mathrm{~h}$.

After addition of $50 \mathrm{ml}$ diethylether the mixture was washed with $\mathrm{HCl}(3 \times 20 \mathrm{ml}, 3 \mathrm{M})$. The organic extract was dried $\left(\mathrm{Na}_{2} \mathrm{SO}_{4}\right)$, filtered and evaporated under a reduced pressure. The residue was further dried in a desiccator $\left(\mathrm{SiO}_{2}\right)$ under a reduced pressure for $12 \mathrm{~h}$ and recrystalised from hot methanol to give the calix[4]arene $\mathbf{3 b}(0.17 \mathrm{~g}, 55 \%)$ as off-white cubes; $\operatorname{mp} 88-90{ }^{\circ} \mathrm{C} ; v_{\max }(\mathrm{Nujol}) / \mathrm{cm}^{-1} 1646(\mathrm{C}=\mathrm{O}), 1605(\mathrm{C}=\mathrm{C})$; $\delta_{\mathrm{H}}\left(270 \mathrm{MHz} ; \mathrm{CDCl}_{3}\right) 7.28(4 \mathrm{H}, \mathrm{d}, J$ 15.1, $\mathrm{Ar}-\mathrm{CH}=), 6.82$ $(8 \mathrm{H}, \mathrm{s}, \mathrm{Ar}-\mathrm{H}), 6.49(4 \mathrm{H}, \mathrm{d}, J$ 15.1, $\mathrm{Ar}-\mathrm{CH}=\mathrm{CH}-\mathrm{C}=\mathrm{O}), 4.41$ $\left(4 \mathrm{H}, \mathrm{d}, J 13.2, \mathrm{CH}_{\mathrm{A}} \mathrm{H}_{\mathrm{B}} \mathrm{Ar}\right), 3.90\left(8 \mathrm{H}, \mathrm{t}, J 7.4, \mathrm{CH}_{2} \mathrm{O}\right), 3.6-3.4$ $\left(16 \mathrm{H}, \mathrm{m}, \mathrm{CH}_{2} \mathrm{NCH}_{2}\right), 3.20\left(4 \mathrm{H}, \mathrm{d}, J 13.2, \mathrm{CH}_{\mathrm{A}} H_{\mathrm{B}} \mathrm{Ar}\right), 1.90$ $\left(8 \mathrm{H}, \mathrm{m}, \mathrm{CH}_{2} \mathrm{CH}_{2} \mathrm{O}\right), 1.70-1.40\left(32 \mathrm{H}, \mathrm{m}, \mathrm{OCHCH}_{2} \mathrm{CH}_{2}\right.$ and $\left.\mathrm{CH}_{2} \mathrm{CH}_{2} \mathrm{CH}_{2} \mathrm{CH}_{2} \mathrm{NCH}_{2}\right), 1.00\left(12 \mathrm{H}, \mathrm{t}, J 8.3, \mathrm{CH}_{3} \mathrm{CH}_{2}\right) ; \delta_{\mathrm{C}}$ $\left(\mathrm{CDCl}_{3}\right)$ 165.9, 158.2, 142.3, 136.1, 130.1, 128.8, 115.9, 75.5, 47.1, 43.3, 32.5, 30.8, 26.7, 24.7, 19.5, 14.1; $\mathrm{m} / \mathrm{z}$ (EI) 1198 [M+]. Found $\mathrm{C}, 75.10 ; \mathrm{H}, 8.23 ; \mathrm{N}, 4.52 \% \mathrm{C}_{76} \mathrm{H}_{100} \mathrm{~N}_{4} \mathrm{O}_{8} \cdot \mathrm{H}_{2} \mathrm{O}$ requires C, $75.09 ; \mathrm{H}, 8.46 ; \mathrm{N}, 4.61 \%$.

$5,11,17,23$-Tetrakis $[(E)-N$-(morpholinyl)-acrylamido]-25,26, 27,28-tetra-n-butoxycalix[4]arene 3c. Triethylamine $(0.335 \mathrm{ml}$, $0.157 \mathrm{~g}, 1.56 \mathrm{mmol})$ and acryloylmorpholine $2 \mathrm{c}(0.294 \mathrm{~g}$, $2.08 \mathrm{mmol}$ ) were added to a stirred solution of $5,11,17,23-$ tetraiodocalixarene-25,26,27,28-tetra- $n$-butylether $\quad(0.3 \mathrm{~g}$, $0.26 \mathrm{mmol}) 1$ in DMF $(20 \mathrm{ml})$. After $10 \mathrm{~min}$ of vigorous stirring at $25^{\circ} \mathrm{C}$, palladium acetate $(0.006 \mathrm{~g}, 0.026 \mathrm{mmol})$ and diphenylphosphinopropane $(0.011 \mathrm{~g}, 0.026 \mathrm{mmol})$ were added and the mixture heated to $100{ }^{\circ} \mathrm{C}$ and stirred for $275 \mathrm{hrs}$.

After addition of $50 \mathrm{ml}$ diethylether the mixture was washed with $\mathrm{HCl}(3 \times 20 \mathrm{ml} 3 \mathrm{M} \mathrm{HCl})$. The organic extract was dried $\left(\mathrm{Na}_{2} \mathrm{SO}_{4}\right)$, filtered and evaporated under reduced pressure. The residue was further dried in a desiccator $\left(\mathrm{SiO}_{2}\right)$ under reduced pressure for $12 \mathrm{hrs}$ and recrystalised from methanol to give the calix[4]arene $3 \mathrm{c}(0.14 \mathrm{~g}, 40 \%)$ as light brown cubes; $\mathrm{mp} 254-256{ }^{\circ} \mathrm{C} ; v_{\max }(\mathrm{Nujol}) / \mathrm{cm}^{-1} 1645(\mathrm{C}=\mathrm{C}) 1620(\mathrm{C}=\mathrm{O})$; $\delta_{\mathrm{H}}\left(270 \mathrm{MHz} ; \mathrm{CDCl}_{3}\right) 7.32(4 \mathrm{H}, \mathrm{d}, J 15.5, \mathrm{Ar}-\mathrm{CH}=), 6.82(8 \mathrm{H}$, $J$ 13.4, s, Ar-H), $6.46(4 \mathrm{H}, \mathrm{d}, J 15.5, \mathrm{Ar}-\mathrm{CH}=\mathrm{CH}-\mathrm{C}=\mathrm{O}), 4.42$ $\left(4 \mathrm{H}, \mathrm{d}, J 13.5, \mathrm{CH}_{\mathrm{A}} \mathrm{H}_{\mathrm{B}} \mathrm{Ar}\right), 3.90\left(8 \mathrm{H}, \mathrm{t}, J 7.5, \mathrm{CH}_{2} \mathrm{O}\right), 3.73-3.56$ $\left(16 \mathrm{H}, \mathrm{m}, \mathrm{H}_{2} \mathrm{COCH}_{2}\right), 3.72-3.70\left(16 \mathrm{H}, \mathrm{m}, \mathrm{H}_{2} \mathrm{CN}(\mathrm{CO}) \mathrm{CH}_{2}\right), 3.19$ (4H, d, $\left.J 13.5, \mathrm{CH}_{\mathrm{A}} \mathrm{H}_{\mathrm{B}} \mathrm{Ar}\right), 1.90-1.88\left(8 \mathrm{H}, \mathrm{m}, \mathrm{CH}_{2} \mathrm{CH}_{2} \mathrm{O}\right), 1.50$ $1.44\left(8 \mathrm{H}, \mathrm{m}, \mathrm{OCHCH}_{2} \mathrm{CH}_{2}\right), 1.00\left(12 \mathrm{H}, \mathrm{t}, J 8.3, \mathrm{CH}_{3} \mathrm{CH}_{2}\right) ; \delta_{\mathrm{C}}$ $\left(\mathrm{CDCl}_{3}\right)$ 165.7, 158.3, 143.1, 135.3, 129.4, 128.0, 114.3, 75.2, $66.8,45.5,42.1,32.3,30.9,19.3,14.1 ; \mathrm{m} / z(\mathrm{EI}) 1206[\mathrm{M}+]$. Found C, 65.49; H, 7.35; N, $4.13 \% \mathrm{C}_{72} \mathrm{H}_{92} \mathrm{~N}_{4} \mathrm{O}_{12} \cdot 6 \mathrm{H}_{2} \mathrm{O}$ requires C, $65.83 ; \mathrm{H}, 7.98 ; \mathrm{N}, 4.27 \%$.

$5,11,17,23$-Tetrakis $[(E)-N$-(methylbenzyl)-acrylamidol-25,26, 27,28-tetra-n-butoxycalix[4]arene 3d. Triethylamine $(0.335 \mathrm{ml}$, $0.157 \mathrm{~g}, 1.56 \mathrm{mmol})$ and methylbenzylacrylamide $2 \mathrm{~d}(0.364 \mathrm{~g}$, $2.08 \mathrm{mmol}$ ) were added to a stirred solution of $5,11,17,23$ tetraiodocalixarene-25,26,27,28-tetra- $n$-butylether $\quad(0.3 \mathrm{~g}$, $0.26 \mathrm{mmol}) 1$ in DMF $(20 \mathrm{ml})$. After $10 \mathrm{~min}$ of vigorous stirring at $25{ }^{\circ} \mathrm{C}$, palladium acetate $(0.006 \mathrm{~g}, 0.026 \mathrm{mmol})$ and diphenylphosphinopropane $(0.011 \mathrm{~g}, 0.026 \mathrm{mmol})$ were added, the mixture heated to $100{ }^{\circ} \mathrm{C}$ and stirred $325 \mathrm{~h}$. After addition of $50 \mathrm{ml}$ diethylether the mixture was washed with $\mathrm{HCl}(3 \times 20 \mathrm{ml}, 3 \mathrm{M})$. The organic extract was dried $\left(\mathrm{Na}_{2} \mathrm{SO}_{4}\right)$, filtered and evaporated under a reduced pressure. The residue was further dried in a desiccator $\left(\mathrm{SiO}_{2}\right)$ under a reduced pressure for $12 \mathrm{~h}$ and purified via column chromatography $(1: 5$
EtOAc-Hexane, $\left.\mathrm{SiO}_{2}\right)$ to give the calix[4]arene 3d $(0.19 \mathrm{~g}$, $55 \%)$ as brown cubes; $\mathrm{mp} 98-100{ }^{\circ} \mathrm{C} ; v_{\max }(\mathrm{Nujol}) / \mathrm{cm}^{-1}$ $1607(\mathrm{C}=\mathrm{C}), 1648(\mathrm{C}=\mathrm{O}) ; \delta_{\mathrm{H}}\left(270 \mathrm{MHz} ; \mathrm{CDCl}_{3}\right) 7.50-7.16$ $(24 \mathrm{H}, \mathrm{m}, \mathrm{Ar}-\mathrm{CH}=$ and $\mathrm{Ar}-\mathrm{H}$ (benzyl)), 6.80-6.62 (8H, s, $\mathrm{Ar}-\mathrm{H}), 6.41-6.5(4 \mathrm{H}, \mathrm{m}, \mathrm{Ar}-\mathrm{CH}=\mathrm{CH}-\mathrm{C}=\mathrm{O}), 4.69(4 \mathrm{H}, \mathrm{m}$, $\left.\mathrm{CH}_{\mathrm{A}} \mathrm{H}_{\mathrm{B}} \mathrm{Ar}\right), 4.35\left(8 \mathrm{H}, \mathrm{m}, \mathrm{CH}_{2} \mathrm{Ar}\right), 4.0-3.6\left(8 \mathrm{H}, \mathrm{m}, \mathrm{CH}_{2} \mathrm{O}\right), 3.19$ $\left(4 \mathrm{H}, \mathrm{d}, J 13.4, \mathrm{CH}_{\mathrm{A}} H_{\mathrm{B}} \mathrm{Ar}\right), 3.01\left(12 \mathrm{H}, \mathrm{s}, \mathrm{CH}_{3} \mathrm{~N}\right), 1.90(8 \mathrm{H}, \mathrm{m}$, $\left.\mathrm{CH}_{2} \mathrm{CH}_{2} \mathrm{O}\right), 1.50-1.35\left(8 \mathrm{H}, \mathrm{m}, \mathrm{OCHCH}_{2} \mathrm{CH}_{2}\right), 1.00(12 \mathrm{H}, \mathrm{t}$, $J$ 8.3, $\left.\mathrm{CH}_{3} \mathrm{CH}_{2}\right) . \delta_{\mathrm{C}}\left(\mathrm{CDCl}_{3}\right) 167.5,158.1,143.0,142.8,137.2$, 129.6, 128.4, 127.7, 127.6, 122.6, 115.3, 75.1, 53.6, 32.7, 32.4, $30.9,19.4,14.1 ; \mathrm{m} / \mathrm{z}$ (EI) $1342[\mathrm{M}+]$. Found C, 73.20; H, 7.71; $\mathrm{N}, 3.75 \% \mathrm{C}_{88} \mathrm{H}_{100} \mathrm{~N}_{4} \mathrm{O}_{8} \cdot 5 \mathrm{H}_{2} \mathrm{O}$ requires $\mathrm{C}, 73.82 ; \mathrm{H}, 7.74 ; \mathrm{N}$, $3.91 \%$.

5,11,17,23-Tetrakis $[(E)-N$-(4-nitrophenyl)-acrylamido]-25,26, 27,28-tetra-n-butoxycalix[4]arene 5a. Triethylamine $(0.335 \mathrm{ml}$, $0.157 \mathrm{~g}, 1.56 \mathrm{mmol})$ and 4-nitrophenylacrylamide $4 \mathbf{a}(0.399 \mathrm{~g}$, $2.08 \mathrm{mmol}$ ) were added to a stirred solution of $5,11,17,23-$ tetraiodocalixarene-25,26,27,28-tetra- $n$-butylether $\quad(0.3 \mathrm{~g}$, $0.26 \mathrm{mmol}) 1$ in DMF $(20 \mathrm{ml})$. After $10 \mathrm{~min}$ of vigorous stirring at $25^{\circ} \mathrm{C}$, palladium acetate $(0.006 \mathrm{~g}, 0.026 \mathrm{mmol})$ and diphenylphosphinopropane $(0.011 \mathrm{~g}, 0.026 \mathrm{mmol})$ were added, the mixture heated to $100{ }^{\circ} \mathrm{C}$ and stirred for $48 \mathrm{hrs}$.

After addition of $50 \mathrm{ml}$ DCM the mixture was washed with $\mathrm{HCl}(3 \times 20 \mathrm{ml}, 3 \mathrm{M})$. The organic extract was dried $\left(\mathrm{Na}_{2} \mathrm{SO}_{4}\right)$, filtered and evaporated under a reduced pressure. The residue was further dried in a desiccator $\left(\mathrm{SiO}_{2}\right)$ under a reduced pressure for $12 \mathrm{~h}$ and recrystalised from hot methanol to give the calix[4]arene $\mathbf{5 a}(0.15 \mathrm{~g}, 51 \%)$ as off-white cubes; $\mathrm{mp} 151-154{ }^{\circ} \mathrm{C} ; v_{\max }(\mathrm{Nujol}) / \mathrm{cm}^{-1} 3384(\mathrm{~N}-\mathrm{H}), 1748(\mathrm{C}=\mathrm{O})$, $1615(\mathrm{C}=\mathrm{C}) ; \delta_{\mathrm{H}}\left(270 \mathrm{MHz} ; d_{6}\right.$-DMSO $) 10.65(4 \mathrm{H}, \mathrm{s}, \mathrm{NH}), 8.05$ $(8 \mathrm{H}, \mathrm{d}, J$ 9.0, Ar-H (nitrobenzene)), $7.36(8 \mathrm{H}, \mathrm{d}, J$ 9.0, $\mathrm{Ar}-$ $\mathrm{H}$ (nitrobenzene), $7.37(4 \mathrm{H}, \mathrm{d}, J 15.5, \mathrm{Ar}-\mathrm{CH}=), 7.00(8 \mathrm{H}, \mathrm{s}$, $\mathrm{Ar}-\mathrm{H}), 6.48(4 \mathrm{H}, \mathrm{d}, J 15.5, \mathrm{Ar}-\mathrm{CH}=\mathrm{CH}-\mathrm{C}=\mathrm{O}), 4.44(4 \mathrm{H}, \mathrm{d}$, $J$ 13.5, $\left.\mathrm{CH}_{\mathrm{A}} \mathrm{H}_{\mathrm{B}} \mathrm{Ar}\right), 3.96\left(8 \mathrm{H}, \mathrm{t}, J 6.8, \mathrm{CH}_{2} \mathrm{O}\right), 3.37(4 \mathrm{H}, \mathrm{d}, J$ 13.5, $\left.\mathrm{CH}_{\mathrm{A}} \mathrm{H}_{\mathrm{B}} \mathrm{Ar}\right), 1.90\left(8 \mathrm{H}, \mathrm{m}, \mathrm{CH}_{2} \mathrm{CH}_{2} \mathrm{O}\right), 1.50-1.47(8 \mathrm{H}, \mathrm{m}$, $\left.\mathrm{OCHCH}_{2} \mathrm{CH}_{2}\right), 1.02\left(12 \mathrm{H}, \mathrm{t}, J 8.3, \mathrm{CH}_{3} \mathrm{CH}_{2}\right) ; \delta_{\mathrm{c}}\left(d_{6}-\mathrm{DMSO}\right)$ $165.0,158.9,146.3,142.6,142.3,135.8,129.1,128.8,125.6$, 126.1, 119.7, 75.2, 36.2, 32.5, 19.2, 14.2; $\mathrm{m} / \mathrm{z}$ (EI) 1409 [M+]; found $\mathrm{C}, 66.88 ; \mathrm{H}, 5.52 ; \mathrm{N}, 7.60 \% \mathrm{C}_{80} \mathrm{H}_{80} \mathrm{~N}_{8} \mathrm{O}_{16} \cdot 2 \mathrm{H}_{2} \mathrm{O}$ requires $\mathrm{C}, 66.47 ; \mathrm{H}, 5.86 ; \mathrm{N}, 7.75 \%$.

5,11,17,23-Tetrakis $[(E)-N$-(4-cyanophenyl)-acrylamidol-25,26, 27,28-tetra-n-butoxycalix[4]arene $\mathbf{5 b}$. Triethylamine $(0.335 \mathrm{ml}$, $0.157 \mathrm{~g}, 1.56 \mathrm{mmol})$ and 4-cyanophenylacrylamide $4 \mathrm{~b}(0.33 \mathrm{~g}$, $2.08 \mathrm{mmol}$ ) were added to a stirred solution of $5,11,17,23$ tetraiodocalixarene-25,26,27,28-tetra- $n$-butylether $1(0.3 \mathrm{~g}$, $0.26 \mathrm{mmol})$ in DMF $(20 \mathrm{ml})$. After $10 \mathrm{~min}$ of vigorous stirring at $25{ }^{\circ} \mathrm{C}$, palladium acetate $(0.006 \mathrm{~g}, 0.026 \mathrm{mmol})$ and diphenylphosphinopropane $(0.011 \mathrm{~g}, 0.026 \mathrm{mmol})$ were added, the mixture heated to $100^{\circ} \mathrm{C}$ and stirred for $24 \mathrm{~h}$. After addition of $50 \mathrm{ml} \mathrm{DCM}$ the mixture was washed with $\mathrm{HCl}(3 \times 20 \mathrm{ml}$, $3 \mathrm{M})$. The organic extract was dried $\left(\mathrm{Na}_{2} \mathrm{SO}_{4}\right)$, filtered and evaporated under a reduced pressure. The residue was further dried in a desiccator $\left(\mathrm{SiO}_{2}\right)$ under a reduced pressure for $12 \mathrm{~h}$ and purified via column chromatography $\left(\mathrm{SiO}_{2}\right.$, EtOAc-hexane $1: 2)$ to give the calix[4]arene $\mathbf{5 b}(0.19 \mathrm{~g}, 55 \%)$ as off-white cubes; mp $180-183{ }^{\circ} \mathrm{C} ; v_{\max }(\mathrm{Nujol}) / \mathrm{cm}^{-1} 3312(\mathrm{~N}-\mathrm{H}), 2228$ $(\mathrm{CN}), 1686(\mathrm{C}=\mathrm{O}), 1604(\mathrm{C}=\mathrm{C}) ; \delta_{\mathrm{H}}\left(500 \mathrm{MHz} ; d_{6}\right.$-DMSO $)$ $10.43(4 \mathrm{H}, \mathrm{s}, \mathrm{NH}), 7.72(8 \mathrm{H}, \mathrm{d}, J$ 8.8, Ar-H (benzenenitrile)), $7.61(8 \mathrm{H}, \mathrm{d}, J 8.8, \mathrm{Ar}-\mathrm{H}$ (benzenenitrile) $), 7.32(4 \mathrm{H}, \mathrm{d}, J$ 15.5, $\mathrm{Ar}-\mathrm{CH}=), 6.97(8 \mathrm{H}, \mathrm{s}, \mathrm{Ar}-\mathrm{H}), 6.42(4 \mathrm{H}, \mathrm{d}, J 15.5$, $\mathrm{Ar}-\mathrm{CH}=C H-\mathrm{C}=\mathrm{O}), 4.41\left(4 \mathrm{H}, \mathrm{d}, J 13.8, C \mathrm{H}_{\mathrm{A}} \mathrm{H}_{\mathrm{B}} \mathrm{Ar}\right), 3.93(8 \mathrm{H}$, $\left.\mathrm{t}, J 6.4, \mathrm{CH}_{2} \mathrm{O}\right), 3.31\left(4 \mathrm{H}, \mathrm{d}, J 13.8, \mathrm{CH}_{A} \mathrm{H}_{\mathrm{B}} \mathrm{Ar}\right), 1.90(8 \mathrm{H}, \mathrm{m}$, $\left.\mathrm{CH}_{2} \mathrm{CH}_{2} \mathrm{O}\right), 1.50-1.38\left(8 \mathrm{H}, \mathrm{m}, \mathrm{OCHCH}_{2} \mathrm{CH}_{2}\right), 1.0012 \mathrm{H}, \mathrm{t}, J$ $\left.8.3, \mathrm{CH}_{3} \mathrm{CH}_{2}\right) ; \delta_{\mathrm{H}}\left(500 \mathrm{MHz} ; \mathrm{CDCl}_{3}\right) 11.20(8 \mathrm{H}, \mathrm{s}, \mathrm{NH}), 8.21$ $(8 \mathrm{H}, \mathrm{d}, J$ 8.7, $\mathrm{Ar}-\mathrm{H}$ (benzenenitrile)), $7.72(8 \mathrm{H}, \mathrm{d}, J$ 8.7, $\mathrm{Ar}-\mathrm{H}$ (benzenenitrile)), $7.05(4 \mathrm{H}, \mathrm{d}, J 15.5, \mathrm{Ar}-\mathrm{CH}=), 6.84(4 \mathrm{H}, \mathrm{s}$, $\mathrm{Ar}-\mathrm{H}), 6.42(4 \mathrm{H}, \mathrm{d}, J$ 15.5, $\mathrm{Ar}-\mathrm{CH}=\mathrm{CH}-\mathrm{C}=\mathrm{O}), 5.77(4 \mathrm{H}, \mathrm{s}$, $\mathrm{Ar}-\mathrm{H}), 4.22\left(4 \mathrm{H}, \mathrm{d}, J 11.8, C \mathrm{H}_{\mathrm{A}} \mathrm{H}_{\mathrm{B}} \mathrm{Ar}\right), 3.74(8 \mathrm{H}, \mathrm{dd}, J 12.7$ $J$ 8.1, $\left.\mathrm{CH}_{2} \mathrm{O}\right), 2.63\left(4 \mathrm{H}, \mathrm{d}, J 11.8, \mathrm{CH}_{A} \mathrm{H}_{\mathrm{B}} \mathrm{Ar}\right), 1.92(8 \mathrm{H}, \mathrm{m}$, 
$\left.\mathrm{CH}_{2} \mathrm{CH}_{2} \mathrm{O}\right), 1.44-1.20\left(8 \mathrm{H}, \mathrm{m}, \mathrm{OCHCH}_{2} \mathrm{CH}_{2}\right), 1.00(12 \mathrm{H}, \mathrm{t}$, $J$ 8.3, $\left.\mathrm{CH}_{3} \mathrm{CH}_{2}\right) ; \delta_{\text {c }}\left(d_{6}\right.$-DMSO) $167.4,155.2,139.9,139.2$, 134.6, 133.9, 127.1, 122.7, 120.3, 119.9, 116.2, 96.3, 76.6, 32.5, $33.0,19.7,15.1 ; \mathrm{m} / z$ (LSIMS) $1329[\mathrm{M}+] ; \mathrm{m} / z$ (ESI, negative ion mode in $\mathrm{MeOH}$ ) $2689.2\left[\mathrm{M}_{2}^{-}+\mathrm{CH}_{3} \mathrm{OH}\right] \mathrm{C}_{165} \mathrm{H}_{164} \mathrm{~N}_{16} \mathrm{O}_{17}$; found $\mathrm{C}, 75.79 ; \mathrm{H}, 6.37 ; \mathrm{N}, 8.29 \% \mathrm{C}_{84} \mathrm{H}_{80} \mathrm{~N}_{8} \mathrm{O}_{8}$ requires $\mathrm{C}$, $75.88 ; \mathrm{H}, 6.06 ; \mathrm{N}, 8.43 \%$.

5,11,17,23-Tetrakis $[(E)-N$-(4-trifluoromethylphenyl)-acrylamido]-25,26,27,28-tetra-n-butoxycalix[4]arene 5c. Triethylamine $(0.335 \mathrm{ml}, 0.157 \mathrm{~g}, 1.56 \mathrm{mmol})$ and 4-trifluoromethylphenylacrylamide $\mathbf{4 c}(0.399 \mathrm{~g}, 2.08 \mathrm{mmol})$ were added to a stirred solution of 5,11,17,23-tetraiodocalixarene $25,26,27,28$ tetra- $n$-butylether $(0.3 \mathrm{~g}, 0.26 \mathrm{mmol}) \mathbf{1}$ in DMF $(20 \mathrm{ml})$. After $10 \mathrm{~min}$ of vigorous stirring at $25{ }^{\circ} \mathrm{C}$, palladium acetate (0.006 g, $0.026 \mathrm{mmol})$ and diphenylphosphinopropane $(0.011 \mathrm{~g}$, $0.026 \mathrm{mmol}$ ) were added, the mixture heated to $100{ }^{\circ} \mathrm{C}$ and stirred for $175 \mathrm{~h}$

After cooling to $\mathrm{rt}$ and addition of $\mathrm{HCl}(50 \mathrm{ml}, 2 \mathrm{M})$ the mixture was filtered and the residue washed with water $(100 \mathrm{ml})$ and methanol $(100 \mathrm{ml})$. The organic extract was dried $\left(\mathrm{Na}_{2} \mathrm{SO}_{4}\right)$, filtered and evaporated under a reduced pressure. The residue was further dried in a desiccator $\left(\mathrm{SiO}_{2}\right)$ under a reduced pressure for $12 \mathrm{~h}$ and recrystalised from methanol to give the calix[4]arene 5c; mp $235-240{ }^{\circ} \mathrm{C} ; \delta_{\mathrm{H}}\left(300 \mathrm{MHz} ; d_{6}\right.$-DMSO) $10.34(4 \mathrm{H}, \mathrm{s}$, $\mathrm{HNCO}), 7.69$ (8H, d, $J$ 10.0, Ar-H (triflouromethylaniline)), $7.43(8 \mathrm{H}, \mathrm{d}, J 10.0, \mathrm{Ar}-\mathrm{H}$ (triflouromethylaniline), $7.25(4 \mathrm{H}, \mathrm{d}$, $J$ 15.10, $\mathrm{Ar}-\mathrm{CH}=), 6.92(8 \mathrm{H}, \mathrm{s}, \mathrm{Ar}-\mathrm{H}), 6.27(4 \mathrm{H}, \mathrm{d}, J 15.20$, $\mathrm{CH}-\mathrm{C}=\mathrm{O}), 4.35\left(4 \mathrm{H}, \mathrm{d}, J 13.8, \mathrm{CH}_{\mathrm{A}} \mathrm{H}_{\mathrm{B}} \mathrm{Ar}\right), 3.89(8 \mathrm{H}, \mathrm{q}, J 6.3$, $\left.\mathrm{OCH}_{2} \mathrm{CH}_{2}\right), 3.30\left(4 \mathrm{H}, \mathrm{d}, J 13.8, \mathrm{CH}_{\mathrm{A}} H_{\mathrm{B}} \mathrm{Ar}\right), 1.89-1.72(8 \mathrm{H}, \mathrm{m}$, $\mathrm{CH}_{2} \mathrm{CH}_{2} \mathrm{O}$ ), 1.47-1.37 (8H, m, $\left.\mathrm{OCH}_{2} \mathrm{CH}_{2} \mathrm{CH}_{2}\right), 0.94(12 \mathrm{H}, \mathrm{t}, \mathrm{J}$ 8.2, $\left.\mathrm{CH}_{3} \mathrm{CH}_{2}\right) ; \delta_{\mathrm{C}}\left(d_{6}\right.$-DMSO) $164.5,143.3,141.4,136.7,135.7$, $129.3,129.1,128.1,126.7,126.4,126.3,119.2,74.9,32.0,30.5$, $18.9,14.0 ; \mathrm{m} / z$ (LSIMS) $1525[\mathrm{M}+1 \mathrm{H}+\mathrm{Na}$ )] found $\mathrm{C}, 64.63$; $\mathrm{H}, 5.53 ; \mathrm{N}, 4.59 \% \mathrm{C}_{84} \mathrm{H}_{80} \mathrm{~F}_{12} \mathrm{O}_{8} \mathrm{~N}_{4} \cdot 2 \mathrm{DMF}$ requires $\mathrm{C}, 65.60 ; \mathrm{H}$, $5.75 ; \mathrm{N}, 5.10 \%$.

$5,11,17,23$-Tetrakis $[(E)-N$-(benzyl)-acrylamido]-25,26,27,28tetra-n-butoxycalix[4]arene $\mathbf{5 d}$. Triethylamine $(0.314 \mathrm{ml}$, $0.210 \mathrm{~g}, 2.083 \mathrm{mmol})$ and benzylacrylamide 4d $(0.251 \mathrm{~g}$, $1.56 \mathrm{mmol}$ ) were added to a stirred solution of $5,11,17,23$ tetraiodocalixarene-25,26,27,28 tetra- $n$-butylether $(0.3 \mathrm{~g}$, $0.26 \mathrm{mmol}) 1$ in DMF $(20 \mathrm{ml})$. After $10 \mathrm{~min}$ of vigorous stirring at $25^{\circ} \mathrm{C}$, palladium acetate $(0.006 \mathrm{~g}, 0.026 \mathrm{mmol})$ and diphenylphosphinopropane $(0.011 \mathrm{~g}, 0.026 \mathrm{mmol})$ were added, the mixture heated to $100{ }^{\circ} \mathrm{C}$ and stirred for $48 \mathrm{~h}$.

After addition of $50 \mathrm{ml}$ DCM the mixture was washed with $\mathrm{HCl}(3 \times 20 \mathrm{ml}, 3 \mathrm{M})$. The organic extract was dried $\left(\mathrm{Na}_{2} \mathrm{SO}_{4}\right)$, filtered and evaporated under a reduced pressure. The residue was further dried in a desiccator $\left(\mathrm{SiO}_{2}\right)$ under a reduced pressure for $12 \mathrm{~h}$ and recrystalised from hot methanol to give the calix[4]arene $\mathbf{5 d}(0.21 \mathrm{~g}, 65 \%)$ as pale brown cubes; $\operatorname{mp} 151-154{ }^{\circ} \mathrm{C} ; v_{\max }(\mathrm{Nujol}) / \mathrm{cm}^{-1} 3275(\mathrm{~N}-\mathrm{H}), 1656(\mathrm{C}=\mathrm{O})$, $1542(\mathrm{C}=\mathrm{C}) ; \delta_{\mathrm{H}}\left(270 \mathrm{MHz} ; \mathrm{CDCl}_{3}\right) 7.31-7.19(24 \mathrm{H}, \mathrm{m}, \mathrm{Ar}-$ $\mathrm{CH}=$ \& Ar-H (benzyl)), $6.74(8 \mathrm{H}, \mathrm{s}, \mathrm{Ar}-\mathrm{H}), 6.09$ (4H, d, $J$ 15.5, $\mathrm{Ar}-\mathrm{CH}=\mathrm{CH}-\mathrm{C}=\mathrm{O}), 4.51\left(8 \mathrm{H}, \mathrm{d}, 5.7, \mathrm{CH}_{2} \mathrm{NH}\right), 4.41(4 \mathrm{H}$, $\left.\mathrm{d}, J 13.9, \mathrm{CH}_{\mathrm{A}} \mathrm{H}_{\mathrm{B}} \mathrm{Ar}\right), 3.88\left(8 \mathrm{H}, \mathrm{t}, J 7.8, \mathrm{CH}_{2} \mathrm{O}\right), 3.12(4 \mathrm{H}, \mathrm{d}, J$ 13.9, $\left.\mathrm{CH}_{\mathrm{A}} \mathrm{H}_{\mathrm{B}} \mathrm{Ar}\right), 1.90\left(8 \mathrm{H}, \mathrm{m}, \mathrm{CH}_{2} \mathrm{CH}_{2} \mathrm{O}\right), 1.46-1.39(8 \mathrm{H}, \mathrm{m}$, $\left.\mathrm{OCHCH}_{2} \mathrm{CH}_{2}\right), 1.00\left(12 \mathrm{H}, \mathrm{t}, J 8.3, \mathrm{CH}_{3} \mathrm{CH}_{2}\right) ; \delta_{\mathrm{C}}\left(\mathrm{CDCl}_{3}\right) 165.0$, $157.2,138.3,134.7,128.9,128.2,128.1,128.0,127.5,127.3$, 126.6, 76.6, 43.7, 32.2, 30.1, 19.7, 14.1. $\mathrm{m} / \mathrm{z}$ (EI) 1286 [M+]; found $\mathrm{C}, 75.95 ; \mathrm{H}, 7.17 ; \mathrm{N}, 4.26 \% \mathrm{C}_{84} \mathrm{H}_{92} \mathrm{~N}_{4} \mathrm{O}_{8} \cdot 2 \mathrm{H}_{2} \mathrm{O}$ requires $\mathrm{C}$, $76.33 ; \mathrm{H}, 7.32 ; \mathrm{N}, 4.24 \%$.

5,11,17,23-Tetrakis $[(E)-N$-(4-aminophenyl)-acrylamido|-25,26, 27,28-tetra-n-butoxycalix[4]arene 8. $\mathrm{SnCl}_{2} \cdot 2 \mathrm{H}_{2} \mathrm{O} \quad(0.478 \mathrm{~g}$, $2.2 \mathrm{mmol}$ ) was added to a stirred solution of $5,11,17,23-$ tetranitrophenylacrylamidocalixarene-25,26,27,28-tetra- $n$-butylether 5a $(0.15 \mathrm{~g}, 0.12 \mathrm{mmol})$ in ethanol $(25 \mathrm{ml})$. After $6 \mathrm{~h}$ of vigorous reflux, the mixture was poured onto ice $100 \mathrm{~g}$ and the $\mathrm{pH}$ adjusted to 8 with $\mathrm{NaOH}(2 \mathrm{M})$. The product was extracted with DCM $(2 \times 100 \mathrm{ml})$ and the organic layer stirred with distilled water $(300 \mathrm{ml})$ for $5 \mathrm{~h}$. Separation of the organic layer preceded the removal of the solvent under a reduced pressure. The residue was further dried in a desiccator $\left(\mathrm{SiO}_{2}\right)$ under a reduced pressure for $12 \mathrm{~h}$ to give the calix[4]arene $\mathbf{8}(60 \mathrm{mg}$, $33 \%)$ as light brown shards; $\mathrm{mp} 120-123 ; v_{\max }(\mathrm{Nujol}) / \mathrm{cm}^{-1}$ $3501(\mathrm{~N}-\mathrm{H}), 3384(\mathrm{~N}-\mathrm{H}$ (amide)), $1748(\mathrm{C}=\mathrm{O}), 1615(\mathrm{C}=\mathrm{C})$; $\delta_{\mathrm{H}}\left(270 \mathrm{MHz} ; d_{6}\right.$-DMSO) $9.62(4 \mathrm{H}, \mathrm{s}, \mathrm{NH}), 7.33(8 \mathrm{H}, \mathrm{d}, J 7.8$, $\mathrm{Ar}-\mathrm{H}$ (aminobenzene)), $7.22(4 \mathrm{H}, \mathrm{d}, J 15.5, \mathrm{Ar}-\mathrm{CH}=), 7.04$ $(8 \mathrm{H}, \mathrm{s}, \mathrm{Ar}-\mathrm{H}), 6.48(8 \mathrm{H}, \mathrm{d}, J \mathrm{~J} .8, \mathrm{Ar}-\mathrm{H}$ (aminobenzene)), 6.39 $(4 \mathrm{H}, \mathrm{d}, J$ 15.5, $\mathrm{Ar}-\mathrm{CH}=\mathrm{C} H-\mathrm{C}=\mathrm{O}), 4.80\left(8 \mathrm{H}, \mathrm{s}, \mathrm{NH}_{2}\right), 4.38$ $\left(4 \mathrm{H}, \mathrm{d}, J 11.8, \mathrm{CH}_{\mathrm{A}} \mathrm{H}_{\mathrm{B}} \mathrm{Ar}\right), 3.92\left(8 \mathrm{H}, \mathrm{t}, J 6.4, \mathrm{CH}_{2} \mathrm{O}\right), 3.22(4 \mathrm{H}$, d, $\left.J 11.8, \mathrm{CH}_{\mathrm{A}} \mathrm{H}_{\mathrm{B}} \mathrm{Ar}\right), 1.90\left(8 \mathrm{H}, \mathrm{m}, \mathrm{CH}_{2} \mathrm{CH}_{2} \mathrm{O}\right), 1.46-1.39(8 \mathrm{H}$, $\left.\mathrm{m}, \mathrm{OCHCH}_{2} \mathrm{CH}_{2}\right), 1.00\left(12 \mathrm{H}, \mathrm{t}, J 8.3, \mathrm{CH}_{3} \mathrm{CH}_{2}\right) ; \delta_{\mathrm{c}}\left(d_{6}\right.$-DMSO $)$ $151.4,143.9,143.5,138.1,134.7,127.1,126.9$, 122.7, 120.7, $120.3,113.9,75.2,36.2,32.5,19.2,14.2 ; \mathrm{m} / \mathrm{z}$ (LSMIS) 1289 $[\mathrm{M}+]$; found $\mathrm{C}, 71.75 ; \mathrm{H}, 6.95 ; \mathrm{N}, 8.00 \% \mathrm{C}_{80} \mathrm{H}_{88} \mathrm{~N}_{8} \mathrm{O}_{8} \cdot 2 \mathrm{H}_{2} \mathrm{O}$ requires $\mathrm{C}, 72.48 ; \mathrm{H}, 7.00 ; \mathrm{N}, 8.45 \%$.

$5,11,17,23$-Tetrakis $[(E)-N$-(4-acetamidophenyl)-acrylamido]$\mathbf{2 5 , 2 6 , 2 7 , 2 8}$-tetra- $\boldsymbol{n}$-butoxycalix[4]arene 9. Triethylamine $(0.335 \mathrm{ml}, 0.157 \mathrm{~g}, 1.56 \mathrm{mmol})$ and 4-acrylamidephenylacetamide $(0.428 \mathrm{~g}, 2.10 \mathrm{mmol})$ were added to a stirred solution of $5,11,17,23$-tetraiodocalixarene-25,26,27,28-tetra- $n$-butylether $(0.3 \mathrm{~g}, 0.26 \mathrm{mmol}) 1$ in DMF $(20 \mathrm{ml})$. After $10 \mathrm{~min}$ of vigorous stirring at $25{ }^{\circ} \mathrm{C}$, palladium acetate $(0.006 \mathrm{~g}, 0.026 \mathrm{mmol})$ and diphenylphosphinopropane $(0.011 \mathrm{~g}, 0.026 \mathrm{mmol})$ were added, the mixture heated to $100^{\circ} \mathrm{C}$ and stirred for $275 \mathrm{~h}$.

After addition of $50 \mathrm{ml} \mathrm{HCl}(2 \mathrm{M})$ the mixture was filtered and washed with water $(100 \mathrm{ml})$ and methanol $(100 \mathrm{ml})$. The organic extract was dried $\left(\mathrm{Na}_{2} \mathrm{SO}_{4}\right)$, filtered and evaporated under a reduced pressure. The residue was further dried in a desiccator $\left(\mathrm{SiO}_{2}\right)$ under a reduced pressure for $12 \mathrm{~h}$ and recrystalised from hot methanol to give the calix[4]arene $9(0.15 \mathrm{~g}, 49 \%)$ as dark brown microcrystals; $m p \quad 219-221^{\circ} \mathrm{C} ; v_{\max }($ Nujol $) / \mathrm{cm}^{-1} 3398$ $(\mathrm{N}-\mathrm{H}), 3384(\mathrm{~N}-\mathrm{H}), 1748(\mathrm{C}=\mathrm{O}), 1732(\mathrm{C}=\mathrm{O}), 1615(\mathrm{C}=\mathrm{C})$; $\delta_{\mathrm{H}}\left(300 \mathrm{MHz} ; d_{6}\right.$-DMSO) $10.33\left(4 \mathrm{H}, \mathrm{s}, \mathrm{CH}_{3} \mathrm{CONH}\right), 9.89(4 \mathrm{H}, \mathrm{s}$, $\mathrm{C}=\mathrm{CHCON} H), 7.50(8 \mathrm{H}, \mathrm{d}, J 8.3, \mathrm{Ar}-\mathrm{H}$ (anilide) $), 7.40(8 \mathrm{H}$, $\mathrm{d}, J$ 8.3, Ar-H (anilide)), $7.38(4 \mathrm{H}, \mathrm{d}, J 15.9, \mathrm{Ar}-\mathrm{CH}=), 7.00$ $(8 \mathrm{H}, \mathrm{s}, \mathrm{Ar}-\mathrm{H}), 6.49(4 \mathrm{H}, \mathrm{d}, J 15.9, \mathrm{Ar}-\mathrm{CH}=\mathrm{CH}-\mathrm{C}=\mathrm{O}), 4.39$ $\left(4 \mathrm{H}, \mathrm{d}, J 12.1, \mathrm{CH}_{\mathrm{A}} \mathrm{H}_{\mathrm{B}} \mathrm{Ar}\right), 3.93\left(8 \mathrm{H}, \mathrm{t}, J 6.8, \mathrm{CH}_{2} \mathrm{O}\right), 3.37(4 \mathrm{H}$, d, $\left.J 12.1, \mathrm{CH}_{\mathrm{A}} H_{\mathrm{B}} \mathrm{Ar}\right), 2.02\left(12 \mathrm{H}, \mathrm{s}, \mathrm{CH}_{3} \mathrm{CON}\right), 1.90(8 \mathrm{H}, \mathrm{m}$, $\left.\mathrm{CH}_{2} \mathrm{CH}_{2} \mathrm{O}\right), 1.50-1.47\left(8 \mathrm{H}, \mathrm{m}, \mathrm{OCHCH}_{2} \mathrm{CH}_{2}\right), 1.02(12 \mathrm{H}, \mathrm{t}, J$ 8.3, $\left.\mathrm{CH}_{3} \mathrm{CH}_{2}\right) ; \delta_{\mathrm{c}}\left(d_{6}\right.$-DMSO) 169.2, 165.0, 158.9, 146.3, 142.6, $135.8,129.1,129.0,128.8,125.6,126.1,119.7,75.2,36.2,32.5$, 24.8, 19.2, 14.2; m/z (EI) $1481[\mathrm{M}+\mathrm{Na}]$; found $\mathrm{C}, 69.86 ; \mathrm{H}$, $6.20 ; \mathrm{N}, 6.61 \% \mathrm{C}_{88} \mathrm{H}_{96} \mathrm{~N}_{8} \mathrm{O}_{12} \cdot 4 \mathrm{H}_{2} \mathrm{O}$ requires $\mathrm{C}, 69.09 ; \mathrm{H}, 6.85 ; \mathrm{N}$, $7.32 \%$.

\section{Diffusion NMR spectra}

Diffusion NMR spectra were obtained following the procedure of: E. J. Cabrita and S. Berger, Magn. Reson. Chem., 2001, 39, 142. Typical conditions for diffusion NMR spectra using a Bruker AMX 500 Avance instrument with standard Bruker diffusion software were as follows: $\delta=3 \mathrm{~ms}, \Delta=35 \mathrm{~ms}$, ten gradients from $98 \%$ to $2 \%$ using 256 scans each, using a field gradient tritium/proton cryoprobe.

\section{Acknowledgements}

We would like to thank the EPSRC for a studentship for A. L. G. and the European Union for further financial support (project "Pesticide"; No. ICA2-CT-2000-10002). Furthermore, N. K. would like to thank Prof. A. Danil de Namor, Prof. P. Sammes and Dr S. Faulkner for helpful discussions and Ms J. Peters, $\mathrm{Mr}$ R. Chaundy, Ms N. Walker and Mr J. Bloxsidge for their excellent technical support. We acknowledge the excellent service of the EPSRC National Mass Spectrometry Service in Swansea. 


\section{References}

1 A. M. Lesk, Introduction to Protein Architecture, Oxford University Press, Oxford, 1st edn, 2001.

2 L. J. Prins, D. N. Reinhoudt and P. Timmerman, Angew. Chem., Int. Ed., 2001, 40, 2382.

3 C. Hamann, K. D. Shimizu and J. Rebek, Jr., Angew. Chem., Int. Ed. Engl., 1996, 37, 1526.

4 K. D. Shimizu and J. Rebek, Jr., Proc. Natl. Acad. Sci. USA, 1995, 92, 12403.

5 (a) J. Rebek, Jr., Chem. Commun., 2000, 637; (b) F. Hof, S. L. Craig, C. Nuckolls and J. Rebek, Jr., Angew. Chem. Int. Ed., 2002, 41, 1488. 6 O. Mogck, V. Böhmer and W. Vogt, Tetrahedron, 1996, 52, 8489.

7 A. M. Rincon, P. Prados and J. de Mendoza, Eur. J. Org. Chem., 2002, 640 .

8 L. Frish, F. Sansone, A. Casnati, R. Ungaro and Y. Cohen, J. Org. Chem., 2000, 65, 5026.

9 M. Lazzarotto, F. Sansone, L. Baldini, A. Casnati, P. Cozzini and R. Ungaro, Eur. J. Org. Chem., 2001, 66, 595.

10 L. R. MacGillivray and J. L. Atwood, Nature, 1997, 389, 469.

11 F. Carbellini, L. Di Constanzo, M. Crego-Calama, S. Geremia and D. N. Reinhoudt, J. Am. Chem. Soc., 2003, 125, 9946.

12 R. Zadmard, M. Junkers, T. Schrader, T. Grawe and A. Kraft, J. Org. Chem., 2003, 68, 6511; R. Zadmard, A. Kraft, T. Schrader and U. Linne, Chem. Eur. J., 2004, 10, 4233.

13 N. Kuhnert and A. Le-Gresley, Chem. Commun., 2003, 2426-2427.
14 N. Kuhnert and A. Le-Gresley, J. Chem. Soc., Perkin Trans. 1, 2001, 3393.

15 N. Kuhnert, A. Lopez-Periago and G. M. Rossignolo, Org. Biomol. Chem., 2003, 1, 1157.

16 The number of 120 possible isomers uses the assumption that mon-, di-, tri- and tetra-substitution products are possible as $\alpha$ - or $\beta$ insertion products, in cis or trans stereochemistry and in various calix[4]arene conformations such as cone, 1,2-alternate and 1,3alternate.

17 H. C. Zhao, P. Ming-Zhong, Y. Chun; and C. S. Song, J. Chem. Res., 2002, 28.

18 C. D. Gutsche, Aldrichim. Acta, 1995, $28,7$.

19 O. Mogck, M. Pons and V. Böhmer, J. Am. Chem. Soc., 1997, 119, 5706.

20 C. W. Haigh and R. B. Mallion, Progr. Nucl. Magn. Reson. Spectrosc., 1980, 33, 303 .

21 L. Frish, M. O. Vysotsky, S. E. Mathews, V. Böhmer and Y. Cohen, J. Chem. Soc., Perkin Trans. 2, 2002, 88.

22 L. Frish, S. E. Mathews, V. Böhmer and Y. Cohen, J. Chem. Soc., Perkin Trans. 2, 1999, 669.

23 C. E. Atkinson, A. E. Aliev and W. B. Motherwell, Chem. Eur. J., 2003, 9, 1714; Y. Cohen, L. Avram and L. Frish L., Angew. Chem., Int. Ed., 2005, 44, 520 (and references cited therein).

24 J. A. Brunink, W. Verboom, J. F. Engbersen, S. Harkema and D. N. Reinhoudt, Recl. Trav. Chim. Pays-Bas, 1992, 111, 511 (acrylamides). 